4.2. Lektura Listów Katolickich przygotowuje do lektury pastoralnej listów papieskich. Należy bowiem o wiele więcej i obficiej wykorzystywać listy Jana Pawła II w przepowiadaniu (encykliki, adhortacje, różnego rodzaju listy). Dobrym materiałem do analizy teologiczno-duszpasterskiej na rekolekcje, dni skupienia, kazania okolicznościowe jest List apostolski z okazji Międzynarodowego Roku Młodzieży, wydany 31 marca 1985 r. Chodzi tylko o odpowiednie wykorzystanie zawartej tam nauki, a nie o nudzące cytowanie. Ze zdań i słów tekstu możemy zrobić parafrazę homiletyczną, czego przykładem jest literatura patrystyczna.

4.3. Rodzaj literacki listu pozostaje dalej formą przepowiadania. Zwróćmy uwagę na charakterystyczny pod tym względem tekst z Konstytucji dogmatycznej Dei verbum: ,Swięci autorowie napisali cztery Ewangelie (...) zachowując formę przepowiadania" (n. 19). Teksty biblijne $\mathrm{w}$ ogóle są same $\mathrm{z}$ siebie przepowiadaniem. Odczytywane często w naszych kościołach listy pasterskie winny mieć swój prawzór w pierwszych listach pasterskich chrześcijaństwa. Chodzi przecież o to, aby słowo Boże w nas owocowało (por. np. Kol 1,6).

Kraków

KS. JERZY CHMIEL

\title{
Krzysztof Pilarezyk
}

\section{EWANGELIA I DZIEJE APOSTOLSKIE SW. LUKASZA - BIBLIOGRAFIA PUBLIKACJI W POLSCE ZA LATA 1945-1985}

W wyniku rozwoju nauk biblijnych, a zwłaszcza studiów nad Nowym Testamentem, po II wojnie światowej wzrosło zainteresowanie Lukanami, tj.: Ewangelią i Dziejami Apostolskimi św. Łukasza. Ukazały się liczne introdukcje, komentarze, monografie i artykuły zajmujące się filologiczną, historyczną i teologiczną problematyką całości lub części Łukaszowego „Doppelwerk”, a także powstały specjalne przeglądy bibliograficzne przedstawiające kierunki i stan badań nad pismami Łukasza ${ }^{1}$.

1 Por. A. J. Matti11: Luke as Historian in Criticism since 1840, Diss. Vanderbildt University 1959; H. Conze $1 \mathrm{~m}$ a n n: Die Mitte der Zeit. Studien zur Theologie des Lukas, Tübingen 1954, 61977; J. D u p o n t: Les sources du Livre des Actes, Bruges 1960; W. Bied er: Die Apostelgeschichte in der Historie, Züich $1960 ;$ C. $K$. B a r ret. Luke the Historian in Fecent Stuciy, London 1961; E. Haenchen: Die Apostelgeschichte, Göttingen 1961, ${ }^{17} 1977$ (KEK NT, 3); D. Guthrie: Recent Literature on the Acts of the Apostles, "Vox Evangelica", II, ed. by R. B. Martin, London 1963; L. E. K e ck, J. L. M a r y n: Studies in Luke - Acts (FS P. Schubert), Nashville-New York 1966; H. S c h ù r m a n n: Das Lukasevangelium. 1. Teil (Kap. 1-9), Leipzig 1971; F. N e i r y n c k: L'Evangile de Luc. Protlémes littéraíes et théologiques (Memorial L. Cerfaux), Gembloux 1973; G. Brauman n: Das Lukasevangelium. Die redaktions - und komposifionsgeschichtliche Forschung, Darmstadt 1974; W. Gasque: A History of the Criti- 
W związku z tym, że ogólnoświatowe bibliografie biblistyczne (np. Elenchus Bibliographicus Biblicus", ,Internationale Zeitschriftenschau für Bibelwissenschaft und Grenzgebiete" czy „New Testament Abstracts") nie zawierają większości polskich prac poświęconym Lukanom, a i polskie bibliografie biblistyczne (doprowadzone do 1976 r. ${ }^{2}$ ) nie odnotowuja ich oddzielnie, zrodziła się potrzeba ułożenia polskiej bibliografii monohagiograficznej, na wzór A Bibliography for the Gospel of Mark 1945-1980 H. M. Humphrey'a ${ }^{3}$, na co pozwala mnogość rodzimych publikacji i tłumaczeń dotyczących tej grupy ksiąg NT, które ukazały się w Polsce w latach $1945-1985$.

Niniejsza bibliografia 1. zawiera prace wyłącznie dotyczące Lukanów i ich autora (redaktora), 2. wskazuje na te fragmenty prac poświęconych, całości Biblii lub tylko NT, które odnosza się do pism Eukasza i 3. odnotowuje artykuły w periodykach i pracach zbiorowych im poświęcone. Wyłaczone. z niej zostały przekłady tekstów biblijnych (odstępstwo uczyniono wobec tzw. "Biblii Poznańskiej”, która w porównaniu z innymi wydaniami Pisma świętego posiada znacznie rozbudowany komentarz do tekstu i obszerniejsze wstępy do poszczególnych ksiąg) i recenzje.

Układ publikacji został ujęty wedlug następującego ,klucza”, przy zachowaniu alfabetycznego układu nazwisk autorów w poszczególnych częściach:

\title{
I. Introdukcje
}

II. Komentarze

III. Problemy filologiczne

IV. Życie Jezusa

1. Ewangelia dzieciństía

2. Publiczna działalność

3. Proces i męka

4. Misterium paschalne

V. Kerygmat Jezusa i apostołów

VI. Pierwotna wspólnota chrześcijańska

VII, Postacie biblijne

VIII. Prace porównawcze

IX. Problemy historyczno-filczoficzne

$\mathrm{X}$. Inne publikacje

\begin{abstract}
cism of the Acts of the Apostles, Tubingen 1975; K. Grös s e r: Acta-Forschung. seit 1960, "Theologische Rundschau" 41 (1976) $259-29 \mathrm{z}$ i 42 (1977) 1-68; E. R a s e : La theobogia du Lucas. Origen, desarrollo, orientaciónes, Rome 1976; G. Sch $\mathrm{s}$ e ider: Das Evangelium nach Lukas, Güersloh-Wirzburg 1977, Bd. 1-2 (Okumenischer Kommentar zum NT, III, 1-2; F. Ernst: Das Evangelium nach Lukas, Regensburg 1977; L. T. John'son: The Literary Funktion of Possessions in Luke-Acts (SBL, Dissertation Series 39), Missoula 1977; R. P. Martin: New Testament Foundations, Vol. 1-2, Grand Rapides 1978; F. Bov on: Luc le théologiem. Vingt-cinq ans ces recherches (1950-1975). Le monde de la Bibble, Neuchâtel-Paris 1978; G. S c hn i d e r: Die Apostelgeschichte, Bd. I-II, Friburg-Basel-Wien 1980-1981 (Fercers Theol. Kommentar zum NT, V, 1-2); M. Re s e:-Neuere Lukas-Arbeiten. Bemerkungen zur gegenwartigen Forschungslage, ,Theologische Literaturzeitung" 106 (1981) 223--228; G. S e hille: Die Aposteigeschichie des Lukas, Berlin 1983. Starszą literature podają komentarze KUL - E. Da brow skiego: Dzieje Apostolskie, Lublin 1961 i F. G r y glewicza: Ewangelia wg św. Eukasza, Eublin 1974. Najobszerniejsza. bibliografię do Dz stanowi A. J. M a t.till, M. B. Mattili: A Classified Bibliography of Literature on the Acts of the Apostels, Leiden 1966 (New. Testament Tools and Studies, ed. B. M. Metzger, VII). 2 zob. S. Grzybek: Polska bibliografia bibitina za lata-1931-1965. Warszawa 1968; J. F r a n k o w k il: Polska bibliografia biblijna adnotowana. 1964-1968, Warszawa 1971; kolejne tomy Polskiej bibliografii neuk kościelnych za lata 1971, $1972-1973$ i $1974-1976$.

3 Zob. Rec. M.-J. Pi e r le, RB 3 (1982) 462.
\end{abstract}


Zastosowane w bibliografii skróty objaśnia Encyklopedia Katolicka, Lublin 1973, t. I, a dodatkowo wprowadzone zamieszczam poniżej:

Dzieje Apostolskie

Dąbrowski E.: Dzieje Apostolskie. Wstęp przekład z oryginału - komentarz, Poznań 1961, Pallottinum.

EK

Encyklopedia Katolicka, TN KUL, Lublin 1973-

Ewangelia wg św. Łukasza Gryglewicz F.: Ewangelia według św. Łukasza. Wstęp - przekład z oryginalu - komentarz, Poznań 1974, Pallottinum.

MPWB

Meka Jezusa Chrystusa

Materiały pomocnicze do wykładów z biblistyki. RW KUL Lublin 1975-

Męka Jezusa Chrystusa (praca zbior. pod red. F. Gryglewicza), Lublin 1980, RW KUL.

Studia z teol. św. Eukasza Studia z teologii św. Eukasza (pod red. F. Gryglewicza), Poznań 1973, Księgarnia św. Wojciecha.

Studio lectionem facere

TST

Studio lectionem facere (praca zbior. pod red. S. Łacha i J. Szlagi), Lublin 1980, RW KUL.

„Tarnowskie Studia Teologiczne”, Tarnów.

\section{INTRODUKCJE}

Andrzejewski R., Jóźwiak F.: Wstęp do Dziejów Apostolskich. W: Pismo święte Starego i Nowego Testamentu, Poznań 1975, Księgarnia św. Wojciecha, t. 3 , s. $289-292$.

Ashton J.: Dlaczego napisano Ewangelie, Warszawa 1977, PAX, ss. 112 (rozdz. IV - Ewangeliści, S. 57-71; rozdz. V - Ewangelie synoptyczne, s. $74-92$; § — Łukasz i historia zbawienia, s. 81-86).

Cullmann O.: Zarys historii ksiąg Nowego Testamentu, Warszawa 1968, PAX, ss. 134 (Ek - s. 35-41; Dz - s. 51-53).

Dąbrowski E.: Dzieje Apostolskie (wstęp), s. 33-215.

Dąbrowski E.: Ewangelie. Ich powstanie i rodzaj literacki, Niepokalanów 21949 ss. 168 (zwłaszcza rozdz. V - Ewangelia dla Greków, s. 93-112).

Dąbrowski E.: Prolegomena do dziejów Chrystusa, AK 269 (1948) 375-383.

Dąbrowski E.: Prolegomena do Nowego Testamentu, Poznań \$1960, Księgarnia św. Wojciecha, ss. $\mathrm{X}+$ rozdz. - Ewangelia wedlug św. Łukasza, s. 194-220; rozdz. - Dzieje Apostolskie, s. 238-251).

Dąbrowski E.: Sobór Watykański II a biblistyka katolicka, Poznań 1976. Księgarnia św. Wojciecha, ss. 457 (rozdz. III - Ewangelia i Ewangelie, s. 68-84; rozdz. $\mathrm{X}$ - Ewangelie $\mathrm{w}$ świetle Instrukcji Papieskiej Komisji Biblijnej..., s. 146-207; § 3 - Ewangelia św. Eukasza, s. 173-175).

Dietrich S.: Boży plan zbawienia. Przewadnik biblijny, Warszawa 21970, PAX, ss. 220 (cz. 2 - Dopełnienie się czasów, czyli Wcielenie, s. 109-145; cz. 3 - Czasy ostateczne, czyli czasy Kościoła, s. 147-199; rozdz. I - Wejście Chrystusa do swojego Królestwa i nawiedzenie Kościoła (Księga Dziejów Apostolskich), s. 153-170).

Gryglewicz F.: Ewangelia wg sw. Łukasza (wstęp), s. 35-77.

Gryglewicz F., Szlaga J.: Dzieje Apostolskie, EK 4 (1983) 575-578.

Grzybek S.: Wprowadzenie w Dzieje Apostolskie (Dz 1, 1-2), RBL 19 (1966) $51-56$. 
Halley H. H.: Przewodnik biblijny, Warszawa 1965-1966, „Slowo Prawdy", cz. 1, ss. 240 (rozdz. - Ewangelia Łukasza, s. 125-195), cz. 2, ss. 383 (rozdz. - Dzieje Apostolskie, s. 5-48).

Harrington W:: Klucz do Biblii, Warszawa ${ }^{2} 1984$, PAX, ss. 507 (cz. III - Wypelnienie - Nowy Testament, s. 317-469; rozdz. I - Formacja Ewangelii synoptycznych, s. 319-339; rozdz. IV - Ewangelia św. Eukasza, s. 356-363; rozdz. V - Dzieje Apostolskie, s. 364-373).

Harrington W.: Teologia biblijna, Warszawa 1977, PAX, ss. 447 (zwlaszcza ss. 11, 17, 22, 161, 202-204, 274, 320, 330, 341, 388).

Jakubiec C.: Stare i Nowe Przymierze. Biblia i Ewangelia, Warszawa 1961. Wyd. ss. Loretanek-Benedyktynek, ss. 380 (rozdz. - Ewangelia, s. 205-210; rozdz. - „Ewangelia o dzieciństwie Jezusa”, s. 211-225; § — „Ewangelia o dzieciństwie Jezusa" według Łukasza, s. 218-224; rozdz. Ewangelia o Jezusie Chrystusie, s. 226-272; rozdz. - Ewangelia (objawienia) Jezusa, s. 273-295; rozdz. - Ewangelia o Duchu Swiętym, s. 296-306). Jeus W.: Ewangeliści jako pisarze, WDr 6 (1983) $42-51$.

Jóźwiak F.: Dzieje Apostolskie. W: Wstęp do Nowego Testamentu, Poznań 1969, Pallottinum, s. 300-332.

Kruszyński J.: Dzieje Apostolskie, „Ład Boży” 6 : 1952.

Kudasiewicz J.: Ewangelia, EK 4 (1983) 1375-1377.

Kudasiewicz J.: Ewangelie na nowo odczytane. W: W nurcie zagadnień posoborowych (pod red. B. Bejze) Warszawa 1967, WSL, s. 133-135.

Kudasiewicz J.: Ewangelie synoptyczne. W: Wstęp do Nowego Testamentu, Poznań 1969, Pallottinum, s. 51-297 (rozdz. IV - Ewangelia według św. Eukasza, s. 240—297).

Kudasiewicz J.: Od Ewangelii mówionej do pisanej, AK 441 (1982) $277-292$.

Kudasiewicz J.: Swięty Eukasz Ewangelista jako pisarz i teolog, MPWB (1978) $197-218$.

Langkammer H.: Etyka Nowego Testamentu, Wrocław 1985, Wyd. Wrocławskiej Księgarni Archidiecezjalnej, ss. 276 (zwłaszcza rozdz. IV Pierwotny Kościół, s. 121-147).

Langkammer H.: Teologia Nowego Testamentu, cz. I, Wrocław 1985, Wyd. Wrocławskiej Księgrni Archidiecezjalnej, ss. 291 (cz. I - Jezus Chrystus wczoraj, s. 29-105; rozdz. I - Jezus ziemski u podstaw nowej nauki - Bogu w Ewangeliach, s. 31-53; rozdz. II - Slowa i czyny Jezusa, s. 55-85; rozdz. III - Teologia Jezusowej perspektywy, s. 87-105; cz. II Jezus Chrystus dzisiaj, s. 107-222; rozdz. I - Źródło mów Pańskich (Sprawa królestwa Bożego), s. 109-127; rozdz. IV - Ewangelia Lukasza (Ewangelia o Zbawicielu i zbawieniu), s. $161-181$; rozdz. VI - Dzieje Apostolskie (Teologia ewangelizacji Kościoła apostolskiego), s. 205-222).

Langkammer H.: Wprowadzenie do Ewangelii, MPWB 5 (1982) $49-89$.

Langkammer H.: Wprowadzenie do ksiąg Nowego Testamentu, Wrocław 21982, Wyd. Wrocławskiej Księgarni Archidiecezjalnej, ss. 282 (zwłaszcza § - Ewangelia Eukasza, s. 220-222; § - Dzieje Apostolskie, s. 222223; $\S$ - Paweł i Łukasz, s. 222-226; § - Dzieje Apostolskie i Paweł, s. $227-231)$.

Läpple A.: Od Księgi Rodzaju do Ewangelii, Kraków 21983, Znak, ss. 487 (cz. - Jezus Chrystus - Mesjasz i Kyrios, s. 353-471; § 2 Schemat opisu w czterech Ewangeliach, s. $370-379 ; \S 3$ - Historyczne i geograficzne tło życia Jezusa, s. $380-396 ; \S 4-\mathrm{Czy}$ ideałem ma byé harmonia Ewangelii, s. 397-406; § 5 - Tytuły Jezusa w Ewangeliach, S. 407-422; §8 - Obraz Chrystusa w Ewangelii Eukasza, s. 450-460).

Eyko Z.: Nauki Pisma świętego, Warszawa 1974, Znaki Czasu, ss. 900 (zwlaszcza s. $330-428$ ).

Eyko Z.: Spotkanie z Biblia,. Warszawa 1974, Znaki Czasu, ss. 231 (zwlaszcza s. $83-96,116-134,143$ ). 
Manning F. V.: Biblia, mit czy tajemnica?, Warszawa 1973, PAX, ss. 287 (rozdz. III - Instrukcja Papieskiej Komisji Biblijnej, O historycznej prawdzie Ewangelii i historyczności Ewangelii, s. 135-228; $\$-$ Eukasz jako historyk, s. 157-165).

Martin G., Czytanie Pisma św. jako Słowa Beżego, Kraków 1982, PTT; ss. $146 \div 152$.

McKenzie J.: Moc i mądrość. Interpretacja Nowego Testamentu, Warszawa 1975, PAX, ss, 336 (rozdz. II - Ewangelia, s. 39-62; rozdz. VII Wiedza o Bogu, s. 153-173; rozdz. VIII - Nowe życie w Chrystusie, S. 174-197; rozdz. IX - Kościól, S. 198-227; rozdz. X - Kryzys w. Kościele, S. 228-249).

Moran R:: Chrystus w historii zbawienia, Warszawa 1982. PAX, ss. 338.

Peter M. (red.): Tak mówi Bóg. Ogólne wiadomości o Piśmie świętym, Poznań 1984, I sięgarnia św. Wojciecha, ss, 232 (rozdz. V-Posłannictwo Jezusa Chrystusa, S. 52-82; §-Zbawiciel w. Ewangelii św. Eukasza, s. 64-70; rozdz. VI - Księgi zwane Nowym Testamentem, s. $83-101$; § Zaginione dokumenty pisane, s. 88-89; §- Ewangelie kanoniczne, s. 90-94; $\S$ - Kwestia synoptyczna, s. 94-98; § - Dzieje Apostolskie, s. 99-100).

Poniatowski Z: Nowy Testament w świetle statystyki językowej, Wrocław 1971, Zakł. Narodowe im. Ossolińskich Wyd. PAN, ss. 202.

Poniatowski Z:: Wprowadzenie . w Ewangelie, Warszawa 1971, KiW, ss. 302 (zwłaszcza cz. II - Porównawcza analiza Ewangelii, s. 133-248).

Schelkle K. H.: Teologia Nowego Testamentu, t. 1: Stworzenie, Kraków 1985, Wyd. Apostolstwa Modlitwy, ss. 190 (zwłaszcza s. 40-46, 89-94, 112-124); t. 2: Bóg był w Chrystusie, tamże, 1985, ss. 344 (zwłaszcza s. 9$148,194-239,241-256$ ); t. 3: Etos, tamże, 1984, ss. 342 (zwłaszcza s. $55-64$, $138-143,147-150,159-167,180,186,198-201,234-235,274-275,278-288$, $290-294,299)$.

Schanckenburg R.: Nauka moralna Nowego Testamentu, Warszawa 1983, PAX, ss. 364 (zwiaszcza s. 100-127, 149-173).

Szlaga J.: Ewangelie, EK 4 (1983) 1425-1426.

Szlaga J.: Problematyka historyczno-literacka i teologiczna Dziejów Apostolskich, MPWB 5 (1982) 91-108,

Szymanek E.: Łukaszowe dzieło, „Msza święta” 1963, s. 14-18.

Varillon F.: Zarys doktryny katolickiej, Warszawa 1972, PAX, ss. 638 (rozdz. III - U progu Nowego Testamentu, s. 139-202, zwłaszcza § - Dzieciństwo Chrystusa, s. $173-179 ; \S-$ Początki życia publicznego Jezusa Chrystusa, s. 191-196; rozdz. VII - Misterium paschalne, s. 363-425; $\S$ - Misterium paschalne, s. 404-420; §- Pierwsza wspólnota chrześcijańska, s. $420-425$; rozdz. VIII - Tajemnica Kościola, s. $429-494 ; \S-\mathrm{Ko}$ ściół jest apostolski, s. 473-479).

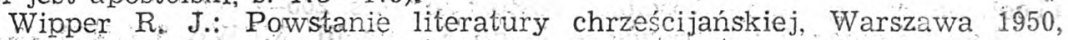
KiW, SS. 323 (zwłaszcza. S. $190-206,266-279,280-284,295-317$ ).

WoIniewicz M.: Wstep do Ewangelii według Eukasza. W: Pismo świete Starego i Nowego Testamentu, Poznan 1975, Ksiegarnia św. Wojciecha, t. 3 , s. $142-146$.

Zanim otworzysz Biblię (red. M. Peter i M. Wolniewicz), Katowice 1981, Ksiegarnia św, Jacka, S,S. 231.

\section{KOMENTARZE}

Ambrozy św.: Wykład Ewangelii wedlug św. Eukasza (Expositio Evangelii S. Lucam). Przekład z tac.W. Szołderski, oprac. i wstep A. Bogucki, Warszawa 1877, ATK, ss. 506.

Andrzejewski R., Jóźwiak F.: Dzieje Apostolskie. W: Pismo święte Starego i Nowego Testamentu, Poznan 1975, Księgarnia ŝ. Wojeiecha, t. 3 , s. $293-347$. 
Andrzejewski R.: Przypowieści o zbawieniu (Ek 15, 4-32) w interpretacji św. Ambrożego z Mediolanu, AK 432 (1981) 63-69.

Barclay W.: Dzieje Apostolskie, Warszawa 1979, Znaki Czasu, ss. 301. SS. 412 :

Barciay W.: Ewangelia Sw. Eukasza, Warszawa 1984, „Slowo Prawdy"

de Boor W.: Dzieje Apostolskie, Warszawa 1980, Zjednoczony Kośció Ewangeliczny, ss. 562.

Dąbrowski E.: Dzieje Apostolskie (komentarz), s. 219-472.

Gryglewicz F.: Egzegeza Dziejów Apostolskich, MPWB (rozdz. 1-3) 3 (1978) 107-137; (rozdz. 4-8) 4 (1979) 3-95; (rozdz. 9-12) 5 (1982) 135-161; (rozdz. 13-18) 6 (1983) 137-182.

Gryglewicz F.: Ewangelia wg św. Eukàsźa (komentarz), s: 79-362.

Jankowski A., Romaniuk K., Stachowiak L.: Komentarz praktyczny do Nowego Testamentu, Poznań 1975, Pallottinum, t. 1: Ewangelia św. Eukaszä, s. 227-358; Dzieje Apostolskie, s. 515-618.

Komentarze do Biblii: pomocne przy badaniu Pisma: św. dla pożytku Pana ofiarowanych świętych, wyczekujących przysposobienią synowskiego i wszystkich, którzy gdziekolwiek wzywają imienia Pańskiego, Kraków 1979, Zrzeszenie Wolnych badaczy Pisma świętëgo, ss. 800 (Ewangelia św. Eukasza, s. 404-470; Dzieje Apostolskie, s. 516-552).

Wolniewicz M.: Ewangelia wedlug Eukasza. W: Pismo święte Starego i Nowégo Testamentu, Poznan 1975, Księgarnia św. Wojciecha, t. 3, S. $147-216$.

\section{PROBLEMY FILOLOGICZNE}

Altbauer M.: Nieznany wariant tekstowy Ek 24, 9, RBL. 33 (1980) $216-219$

Bartnicki R.: Redakcyjne cele ewangelistów w. Ek 19, 29-40 i J 12 , $12-19$, STV 2 (1980) $49-82$.

Czajkowski M.: De lectione ,occidentali" in Lc 3, 22 (O "lekcji ,zachodniej" U ŁK 3, 22), RTK 12: 1965,1, s. 35-44.

Dąbrowski E.: Cytaty z Aratosa i Epimenidesa w mowie na Areopagu (Dz 17, 28). W: Dzieje Apostolskie, s. 542-549.

Dabrowski E.: Mowy w Dziejach Apostolskich. W: Dzieje Apostolskie, s. $526-533$.

Cazelles H., Delorme. J., Derousseaux L., Le Du J., Macé. R.: Język wiary w Piśmie świętym i w świecie współczesnym, Warszawa 1975, PAX, ss. 207 (zwłaszcza rozdz. - Zmartwychwstanie Jezusa w języku Nowego Testamentu, s. 88-168).

Gryglewicz F.: Dziewictwo w greckiej terminologii biblijnej, RTK 22: 1975 , s, s. $26-37$.

Gryglewicz F.: Ewangelia i Dzieje Apostolskie po polsku, „Odra" $19: 1947$.

Gryglewicz F.: Redakcja Łk 8; 15. W: Ewangelia wg św. Eukasza, s. 399-404; również w: SSHT 8 (1975) 19-24.

Klawek A.: Nowy rękopis Ewangelii šw. Eukasza, RBL 15 (1962) $308-309$.

Romaniuk K.: Co to jest źródło Q?, Wàrszawa 1983, ATK, ss. 164 (zwłaszcza s. 6-10, 13-18, 27, 33-36, 38-39, 41-42, 45-51, 53-54, 57-64, $68,72-74,77-82,85-98,100-148)$.

Romaniuk K.: Morfokrytyka i historia redakeji, czyli Form-i Redaktionsgeschichte, Warszawa 1983, ATK, ss. 179 (zwłaszcza s. 10, 17, 22, 24, $30,37-49,64-66,82,87-88,91-97,100,104-110,125-132,150)$.

Szczurek T.: Znaczenie struktur literackich dla hermeneutyki na przykładzie zwiastowań Mt 1, 18-25, Ek 1, 26-38 oraz cudu w Kanie J 2, $1-11$, RBL 28 (1975) 226-228. 


\section{IV. ŻYCIE JEZUSA}

\section{Ewangelia dzieciństwa}

Abramek R. J.: Jednoczące zdanie Maryi z „Ewangelii milosierdzia” (Łk 1, 50) w Dives in misericordia. W: Encyklika Ojca Swiętego Jana Pawła II o Bożym miłosierdziu Dives in misericordia - tekst i komentarz, Kraków 1981. PTT, s. 116-126.

Abramek R. J.: Miłosierdzie i solidarność (w Magnificat), Więź 4 (1981) $64-73$.

Aron R.: Młodociany Jezus u nauczycieli, Więź 7 (1977) 18-36.

Barreau J. C.: Ewangelia dla każdego z nas, Warszawa 1973, PAX, ss. 267 (rozdz. - Opowiadania o dzieciństwie w Ewangelii Łukasza, s. $139-155)$.

Czajkowski M.: Dobra Nowina o narodzeniu Pana, „Tygodnik Powszechny" 24: 1970.

Czajkowski M.: Dwie ewangelie o jednym dzieciństwie, „Tygodnik Powszechny" 24: 1970.

Czekała T.: Łk 1, $34 \mathrm{w}$ egzegezie katolickiej XX wieku, CT 41: 1971, 3 , s. $29-40$.

Czerski J.: Postawy moralne w Ewangelii Dzieciństwa u św. Eukasza (Ek 1-2), „Studia Teologiczno-Historyczne Sląska Opolskiego" 6 (1978) 171-182.

Czubryński A.: Gwiazda Króla Zydowskiego, „Głos Wolnych” 12: 1947.

Fic A.: Jezus Chrystus (Szkice do Ewangelii), Warszawa 21954, Pallottinum, t. 1: Tajemnice dziecięctwa, ss. 228.

Gryglewicz F., Kudasiewicz J.: Ewangelia dzieciństwa, EK 4 (1983) $1381-1384$.

Gryglewicz F.: Magnificat, aspekt teologiczny. W: Z zagadnień kultury chrześcijańskiej, Lublin 1973, TN KUL, s. 99-110.

Gryglewicz F.: Magnificat - aspekt teologiczny i maryjny. W: Ewangelia wg św. Eukasza, s. $380-392$.

Gryglewicz F.: Pochodzenie hymnow Łukaszowej Ewangelii dzieciństwa, „Summarium" 2: 1975, 1, s. 49. $374-380$.

Gryglewicz F.: Poczęcie Jezusa. W: Ewangelia wg Sw. Eukasza, s.

Gryglewicz F.: Słowo ciałem się stało. Pochodzenie Jezusa Chrystusa w Nowym Testamencie, Lublin 1976, TN KUL, ss. 143 (zob. skorowidz miejsc biblijnych (Ek i Dz), s. 138-141).

Gryglewicz F.: Teologia hymnów Eukaszowej Ewangelii Dzieciństwa, Lublin 1975. TN KUL, ss. 121.

Gryglewicz F.: Teologiczne aspekty błogosławieństwa Symeona (Ek 2, 29-35), RTK 19: 1972, 1, s. 73-82.

Gryglewicz F.: Teologiczne aspekty blogosławieństwa Symeona. W:

Ewangelia wg św. Eukasza, s. 392-399.

Grzybek S.: Magnificat anima mea Dominum, RBL 17 (1964) 238-243.

Homerski J.: Starotestamentowe reminiscencje w tekstach maryjnych Łukaszowej Ewangelii Dzieciństwa. W: U boku Syna (pod red. J. Szlagi), Lublin 1984, RW KUL, s. 75-84.

Klawek A.: Ave Maria, RBL 4 (1951) 25-37.

Klawek A.: Betlejem, RBL 2 (1949) 446-448.

Klawek A.: Hymn anielski (Ek 2, 14), RBL 23 (1970) 65-72.

Kokat A.: Magnificat w świetle Psalmów. W: Studia z teol. św. Lukasza, s. $70-87$.

Kudasiewicz J.: Ewangelie dziecięctwa Jezusa, CT 40: 1970, 4. s. $161-170$.

Kudasiewicz J.: Ewangelie dzieciństwa Jezusa - historia czy legenda? W: Studio lectionem facere, s. $134-140$. 
Kudasiewicz J.: Ewangelia dziecięctwa Jezusa - historia czy legenda, WDr 12 (1977) $41-48$.

Kudasiewicz J.: Ewangelia dziecięctwa Jezusa w przepowiadaniu Kościola. W: Chrystus żywy w sakramentach. Materiały III Kursu Homiletyczno-Katechetycznego, Warszawa 1970, ATK, s. 75-98.

Łach J.: Egzegetyczne problemy Łukaszowej Ewangelii dziecięctwa Jezusa, STV 2 (1978) 3-15.

Łach J.: Ewangelia dziecięctwa - historia czy legenda, AK 441 (1982) $304-316$.

Łach J.: Służebna rola Maryi w odkupieniu w świetle relacji o zwiastowaniu (Ek 1, 26-38), RBL 34 (1981) 347-354.

Łach J.: Ze studiów nad teologią dziecięctwa Jezusa. W: Studia z biblistyki, Warszawa 1978, ATK, t. 1, s. 155-325.

Ordon H.: Zwiastowanie Zachariaszowi i Maryi (Ek 1, 5-38) na tle starotestamentalnych schematów literackich, RTK 27: 1980, 1, s. 71-80.

Pirot J.: Magnificat, MDG 6 (1962) 125-127.

Pracz J.: Współczesne głoszenie Ewangelii dziecięctwa w/g Łukasza. RTK 26: 1979,6 , s. $86-89$.

Przybylski R.: Spotkanie z Panem (Ek 2, 22-40), Znak 1 (1983) 3-35.

Rumak J.: Ewangelia dziecięctwa Pana Jezusa a krytycy, RBL 15 (1962) $344-352$.

Scheffczyk L.: „Dziewicze narodziny”: podstawy biblijne i trwale znaczenie, Com (pol.) 5 (1983) 41-54.

Schelkle K. H.: Dzieciństwo Jezusa. W: Biblia dzisiaj (pod red. J. Kudasiewicza), Kraków 1969, PTT, s. 241-262.

Sicari A. M.: „Witaj łono bożego wcielenia”, Com (pol.) 5 (1983) 55-67.

Smereka W.: Betlejem w historii i legendzie, RBL 1 (1948) $339-343$.

Smereka W.: Konfrontacje egzegezy Ewangelii dzieciństwa Chrystusa z próbami odmitologizowania Ewangelii, KDW 56 (1973) 121-130.

Sotowski W.: Ewangelia dziecięctwa według św. Eukasza. W: Chrystus

i Kościól (pod red. F. Gryglewicza), Lublin 1979, RW KUL, s. 11-24. $47-49$.

Strzelecka K.: „Ut putabatur - filius Joseph” (飞k 3, 24), RBL 17 (1964)

Suski A.: W kwestii integralności opisu zwiastowania (Łk 1, 26-38), CT 48: 1978, 3, s. $31-41$.

Szlaga J.: Czas narodzin Jezusa Chrystusa, Znak 11-12 (1977) 13051319.

Szlaga J.: Interpretacja perykopy $\mathrm{kk} 1,35-38$ w kontekście empirycznym Nowego Testamentu, SPelp 10 (1975) 68-80.

Wilk J.: Teologia Eukaszowej Ewangelii dziecięctwa. W: Studia z teol. św. Łukasza, s. 105-124.

Włodarczyk S.: Zwiastowanie Maryi zapowiedzią nadejścia ,pelni czasów”, RBL 36 (1983) 206-213.

Wolniewicz M.: Dwa nawiedzenia świątyni (Ek 2, 40; 2, 52) „Msza święta" 1964, s. 8-9.

Wolniewicz M.: Zbawiciel - Chrystus - Pan w Łukaszowej Ewangelii o dzieciństwie Jezusa, „Msza święta" 1965 , s. 277-280.

Wolniewicz M.: Z Ewangelii o latach dziecięcych Jezusa. W: W kręgu Nowego Przymierza, Poznań 1985, Księgarnia św. Wojciecha, s. 7-68.

\section{Publiczna działalność}

Barreau J. C.: Ewangelia dla każdego $z$ nas, Warszawa 1973, PAX, ss. 267 (rozdz. - Ewangelia Eukasza: Jezus dopelnia swego przeznaczenia w Jerozolimie, s. 172-190).

Bartnicki R.: Początki publicznego życia Jezusa w świetle Ewangelii synoptycznych, HD 2 (1981) 140-146. 
Bartnicki R:: Teologia ewangelistów w perykopie o wjeździe Jezusa do Jerozolimy, STV 2 (1977) 55-76. $209-212$.

Chadam A.: Miejsce drugiego kuszenia Pana Jezusa, RBL I (1948)

Crouzeî H.: Modlitwa Jezusa, Com (pol.) 4 (1985) $39-53$.

Czajkowski M.: Sens antropologiczny czy teologiczny synoptycznych cudów Jezusa? W: Warszawskie studia biblijne (pod red. J. Frankowskiego i B. Widła), Warszawa 1976, ATK, s. 70-87.

Çajkowski M.: Sens cudów Jezusa, Więź 10 (1972) 20-27.

Daniel-Rops H.: Dzieje Chrystusa, Warszawa 1972, PAX, ss. 578 (zwlaszeza s. $37-48,108-149,176-181,206-210 \times 225-239,355-437,442-455)$.

Dąbrowski E.: Życie Jezusa Chrystusa w opisie ewangelistów, Poznań 1957, Pallottinum, ss. 521.

Firlej E: Przemienienie Chrystusa według synoptyków, „Novum" 4-5 (1977) 83-90.

Gryglewicz F.: Za kogo mnie uważacie? Chrystus w oczach swoich współczesnych, Poznań 1966, KiW, ss. 216.

Hergesel T.: Postać Jezusa Cudotwórcy bez retuszu, CS 14 (1982) $181-201$.

Kowalski S.: Spisek Heroda Antypa na życie Chrystusa Pana (Ek 13, $31-33)$, RBL 4 (1951) $380-385$.

Kudasiewicz J.: Chrzest Chrystusa, AK 338 (1965) 15i-164.

- Kudasiewicz J.: Chrzest Jezusa w Jordanie. W: Studio lectionem facere, s, 141-145.

Kudasiewicz J.: Chrzest Jezusa. W: Chrystus i Kościól (pod red.

F. Gryglewicza), Lublin 1979, RW KUL, s. 25-34.

Kudasiewicz J.: Chrzest Pański, EK 3 (1979) 370-371.

Kudasiewicz J.: Literacka i teologiczna problematyka cudów Jezusa.

W: Warszawskie studia biblijne (pod red. J. Frankowskiego i B. Widla),

Warszawa 1976, ATK, s. 88-98.

Kudasiewicz J.: Znaczenie Jeruzalem w czasie działalności galilejskiej Jezusa (Ek 4, 14-9, 50), RTK 17: 1970, 1, s. 43-59.

Kudasiewicz J.: Cuda Jezusa. W: Studio lectionem facere, s. 153-158.

Kudasiewicz J.: Cud (w NT), EK 3 (1979) 648-652.

Langkammer H.: O interpretacji cudów Jezusa, RBL 31 (1978) 193-198. $39-44$.

Each J.: Funkcja cudów w ewangelii Łukaszowej, CT 55: 1985, 3,

Muszyński H.: Kuszenie Chrystusa w tradycji synoptycznej, CT 46: $1976,3,17-42$.

Muszyński H.: Uzdrowienie opętanych. W: Studio lectionem facere,

S. $159-164$.

Obuchowski J.: Znaczenie pustyni, KWD 9 (1981) 171-174.

Poniatowski Z.: Cuda ewangeliczne, Euh 3 (1969) 47-55.

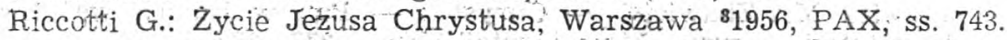

Romaniuk K.: Czynny udział Chrystusa w zbawczej inicjatywie Ojca:

W: Drogi zbawienia. Od Biblii do Soboru (pod red. B. Przybylskiego), Poznan 1970, Księgarnia św. Wojciecha, s. $144-265$.

Smereka W.: Potrójne kuszenie Chrystusa na tle marzen mesjańskich, RBL 9 (1956) 33-51.

White E. G.: Sladami Jezusa, Warszawa 21984, Znaki Czasu, ss. 192.

White E. G.: Życie Jezusa, Warszawa ${ }^{2} 1983$, Znaki Czasu, ss. 668.

Wolniewicz Ma: Wskrzeszenie córki Jaira, „Msza święta" 1965; S. 35-38.

Wolniewicz M.: W Dekapolu (Łk 8, 22-39), „Msza święta”. 1965, s. 9-12.

Wolniewicz M.: W Samarii (Ek 9, 51-62), „Msza święta” 1965, s. $249-252$. 
3. Proces i męka

Bałtowski J.: Gdzie Apostołowie byli w czasie Męki Pana Jezusa? RBL 9 (1956) 82-92.

Barrosse T.: Pascha i wieczerza paschalna, Conc (pol.) 1-10 (1968) $554-560$.

Bartnicki R.: Ewangeliczne zapowiedzi męki, śmierci i zmartwychwstania w świetle kryteriów logiów Jezusa, CT 51: 1981, 2, s. 53-64.

Bartnicki R.: Ostatnia wieczerza a świadomość zbawczej śmierci Jezusa, STV 2 (1930) 313-320.

Bednarz M.: Analiza literacka opisu modlitwy na Górze Oliwnej i pojmania Jezusa (Ek 22, 39-53), SW 12 (1975) 449-462.

Bednarz M.: Eukaszowa koncepcja męki Jezusa. W: Męka Jezusa Chrystusa, s. 97-102.

Bednarz M.: Modlitwy Jezusa w Łukaszowym opisie męki, TST 8 (1981), $97-104$.

Czajkowski M.: Uczniowie podczas męki Chrystusa. W: Męka Jezusa Chrystusa, s. 29-38.

Czerski J.: Męka Pańska w Ewangeliach synoptycznych, CT 46: 1976, 4, s. $29-43$.

Dąbrowski E.: Nova et vetera o „Procesie Chrystusa”. W: Konfrontacje, Poznań 1970, Księgarnia św. Wojciecha, s. 217-235.

Dąbrowski E.: Proces Chrystusa w świetle historyczno-krytycznym, Poznań 81965, Księgarnia św. Wojciecha, ss. 323.

Dąbrowski E.: Wokól „Procesu Chrystusa”. Badania współczesne i ich wyniki, Znak 11 (1964) 1299-1308.

Drozd J.: Ostatnia wieczerza nową Paschą, Katowice 1977, Księgarnia św. Jacka, ss. 207.

Federkiewicz P.: Agonia Chrystusa Pana w Ogrójcu. Uwagi egzegetyczne do Łk 22, 43n., RBL 13 (1960) 119-126.

Gołębiowski F.: Refleksja teologiczna nad męką Chrystusową, WDr 4 (1974) 8-18.

Gryglewicz F.: Jezus przed Piłatem. W: Męka Jezusa Chrystusa, s. $47-57$.

Gryglewicz F.: Krwawy pot Chrystusa Pana. W: Ze współczesnej problematyki biblijnej, Lublin 1961, RW KUL, s. 63-79.

Gryglewicz F., Jóźwiak F.: Maltretowanie Jezusa. W: Męka Jezusa Chrystusa, s. $59-65$.

Gryglewicz F.: Męka Chrystusa w badaniach ostatnich dziesięciu lat, przegląd bibliograficzny, AK 376 (1971) 163-171.

Gryglewicz F.: Znaczenie Jezusowej męki w ujęciu św. Eukasza, RTK 17: 1970,1 , s. $31-42$.

Homerski J.: Pod krzyżem Jezusa. W: Męka Jezusa Chrystusa, s. 67-74.

Homerski J.: Starotestamentalne cytaty i aluzje w ewangelicznych opisach męki i śmierci Jezusa, RTK 26: 1979, 1, s. 13-24.

Jóźwiak F.: ,Jezusa kazał ubiczować i wydał na ukrzyżowanie”. Ewangelia o biczowaniu, cierniem koronowaniu i drodze krzyżowej, AK 393 (1974) $29-43$.

Jóźwiak J.: Męka Chrystusa w Dziejach Apostolskich, AK 437 (1981) $443-456$.

Kłoniecki F.: Krwawy pot Chrystusa Pana zjawiskiem rzeczywistym naturalnym? WAG 12 (1957) 215-218.

Kudasiewicz J.: „Córki jerozolimskie nie płaczcie nade mną", RTK 22: 1975 , 1, s. $39-47$.

Kudasiewicz J.: Jeruzalem - miejscem zbawczej śmierci Jezusa (Ek 24, 13-33), RTK 25: 1978, 1, 69-74.

Langkammer H.: Jezusowe słowa z krzyża. W: Męka Jezusa Chrystusa, s. $75-85$. 
Langkammer H.: Jezus wprowadza uczniów w tajemnicę swojej śmierci. MPWB 3 (1978) 159-202.

Langkammer H.: Wprowadzenie i komentarz do ewangelicznych opisów męki Pańskiej, Lublin 1975, RW KUL, ss. 152.

Lipiński E.: Namaszczenie w Betanii, RBL 12 (1959) 220-229.

Michoń E.: Jezus podczas męki u św. Łukasza. W: Studia z teol. św. Łukasza, s. 46-57.

Niemczyk W.: Od krainy Uz po Golgotę. Zagadnienie cierpienia w reIacjach biblijnych, RT 7 (1965) 213-244.

Poniatowski Z.: Analiza statystyczna ewangelicznego opisu pasji Jezusa, StR 3 (1970) 71-79.

Romaniuk K.: Czy i jak rozumial Jezus cel swej śmierci, RBL 31 (1978) 198-206.

Smereka W.: Annasz i jego udział w procesie Chrystusa, RBL 7 (1954) $139-155$.

Smereka W.: Chrystus w śledztwie Sanhedrynu, ACr 1 (1969) 57-82.

Smereka W.: Proces Chrystusa w świetle najnowszych badań, RBL 15 (1962) $145-160$.

s. $21-27$.

Szojda D.: Modlitwa Jezusa i pojmanie. W: Męka Jezusa Chrystusa,

Szreder F.: Ostatnia wieczerza, SW 12 (1975) 443-448.

Szymanek E.: Wyznanie Jezusa wobec trybunału żydowskiego, HD 2 (1977) $42-49$.

Szymanek E.: Wyznanie Jezusa wobec trybunału żydowskiego. W: Męka Jezusa Chrystusa, s. 39-46.

White E. G.: Cierpienia Chrystusa, Kraków 1949, Znaki Czasu, ss. 31.

Wolfram K.: Męka i chwała Jezusa Chrystusa, Warszawa 1965, ChAT (mps. powiel.).

\section{Misterium paschalne}

Chmiel J.: Stan współczesnych badań biblijnych nad zmartwychwstaniem Jezusa, RBL 27 (1974) 127-138.

Congar Y.: „Trzeciego dnia zmartwychwstal”, WDr 4 (1976) 5-10.

Czajkowski M.: Dobra Nowina o zmartwychwstaniu Pańskim. W: Chrystus i Kościół (pod red. F. Gryglewicza), Lublin 1979, RW KUL, s. 79-86.

Czajkowski M.: Uwielbienie Jezusa - w zmartwychwstaniu czy we wniebowstąpieniu? W: Studio lectionem facere, s. 184-186.

Czajkowski M.: Wniebowstąpienie Jezusa. W: Studia z teol. św. Eukasza, s. 58-71.

Czajkowski M.: Wok6ł zmartwychwstania, WDr 8 (1975) 80—91.

Czajkowski M.: Wstąpił do nieba. W: Chrystus i Kościoł (pod red. F. Gryglewicza), Lublin 1979, RW KUL, s. 87-92.

Dąbek T. M.: H Agapè tou Pneumatos. Związek miłości z Duchem Swiętym w Piśmie świętym Nowego Testamentu, ACr 15 (1983) 105-121. Dola T.: Antropologiczna interpretacja formuły ,zmartwychwstał dnia trzeciego", СT 53: 1983,3 , s. $37-54$.

Duch 'Swięty w życiu Pana Jezusa i w dziele Apostołów według Ewangelii św. Łukasza i Dziejów Apostolskich, MDG 3 (1959) 467-475; również w: WDL 35 (1961) 43-51.

Fic A.: Jezus Chrystus (Szkice do Ewangelii), Warszawa 21954, Pallottinum, t. 2: Tajemnice męki i chwały, ss. 214. $1000-1010$.

Frankowski J.: Zmartwychwstanie Chrystusa, Znak 7-8

Grabner-Haider A.: Zmartwychwstanie i uwielbienie. Spostrzeżenia biblijne, Conc (pol.) 1-5 (1969) 41-50.

Gryglewicz F.: Duch Swięty w ujęciu św. Łukasza, MPWB 7 (1985) $73-80$. 
Hładowski W.: Charakter przekazów wielkanocnych jako problem w badaniach nad wiarygodnością objawienia, STV 1 (1979) 14-24.

Hoła K.: Paschalny charakter ostatniej wieczerzy a data śmierci Jezusa, RBL 38 (1985) $41-44$.

Hryniewicz W.: Chrystus nasza pascha, Lublin 1982, TN KUL, t. 1, ss. 492 (rozdz. II - Misterium paschalne w wierze i przepowiadaniu Kościoła Apostolskiego, s. 87-131).

Jankowski A.: Duch Dokonawca. Nowy Testament o posłannictwie eschatologicznym Ducha Swiętego, Katowice 1983, Księgarnia św. Jacka, ss. 161.

Jankowski A.: Duch Odnowiciel, ACr 4 (1972) 125-145.

Jankowski A.: „Duch Ojca” — „Duch Syna”, Znak 10 (1974) 1227-1238.

Jankowski A.: Duch Swięty a Eucharystia, ACr 8 (1976) 87-110.

Jankowski A.: Jezus a Duch, RBL 36 (1981) 16-21.

Jankowski A.: Kyrios i Pneuma czyli teologia zesłania Ducha Swiętego. W: Drogi zbawienia. Od Biblii do Soboru (pod red. B. Przybylskiego), Poznań 1970, Księgarnia św. Wojciecha, ss. 208-222.

Jankowski A.: Od ducha Jahwe do Ducha Parakleta. Proces tworzenia się pneumatologii biblijnej Nowego Testamentu, RBL 30 (1977) 54-65.

Jankowski A.: Spiritus Consumator, AK 387 (1973) 25-36.

Jankowski A.: Zarys pneumatologii Nowego Testamentu, Kraków 1982 , PTT, ss. 104.

Janowski W.: Wniebowstąpienie Pańskie, „Znaki Czasu” 5 (1949) 8-12.

Kudasiewicz J.: Jeruzalem - miejscem ukazywań zmartwychwstałego

Chrystusa (Ek 24, 1-52), RTK 22: 1974, 1, s. 51-60.

Kudasiewicz J.: Jeruzalem - miejscem zesłania Ducha Swiętego, RTK 23: 1976,1 , s. $85-97$.

Lyonnet S.: Obecność Chrystusa i jego ducha w człowieku, Conc (pol.) 6-10, (1969) 303-311.

Łach J.: Opisy wniebowstąpienia Jezusa. W: W kierunku prawdy (pod red. B. Bejzego), Warszawa 1976, ATK, s. 65-78.

乇ach S.: Miejsce śmierci i zmartwychwstania Chrystusa, RBL 11 (1958), $124-133$.

Łukaszyk R., Szlaga J.: Duch Chrystusa, EK 4 (1983) 281-282.

Martelet G.: Zmartwychwstanie - Eucharystia - człowiek, Warszawa 1976, PAX, ss. 239 (zwlaszcza s. 22-87).

Mazurski J.: Veni Sancte Spiritus, „Kuźnica Kapłańska” 10: 1956.

Milik K.: Albowiem nie są oni, jak mniemacie, pijani..." (Dz. Ap. 2, 15), "Przewodnik Katolicki" 1961, s. 373.

Misiurek J.: Emaus, RBL 31 (1978) 240-246.

Opiela S.: Wokół zdarzenia zmartwychwstania i paschalnego orędzia,

CT 43: 1973, 3, s. 207-210.

Ordon H.: Duch Swięty w Nowym Testamencie jako moc i osoba, MPWB 7 (1985) $81-88$.

Pache R.: Osoba i dzieło Ducha Swiętego, Warszawa 1975, Zjednoczony Kościoł Ewangeliczny, ss. 253.

Pajor R.: Znaczenie chrztu Duchem Swiętym i ogniem, RTK 14: 1967, 1, s. $49-64$.

Peter J. K.: Duch Sw. darem Ojca i źródłem apostolskiej aktywności, PzST 4( 1983) 69-74.

Pilarczyk K.: Znaki wypełnienia się czasu w Dziejach Apostolskich

(Dz 2, 1), „Sługa Zboru" 2 (1984) 11-12.

Poniatowski Z.: Ewangeliczne opowieści o zmartwychwstaniu Jezusa.

Morfologia statystyczna, Euh 1 (1976) 3-14.

Pytel J. K.: Duch Sw. darem Ojca i źródłem apostolskiej aktywności,

PzST 4 (1983) 69-74. 
Religiolog (Czubryński A.): Zesłanie Ducha'Świętego, „Głos Wolnych” 2 (1947) 76-77.

Romaniuk K.: Duch Święty, EK 4 (1983) 282-283.

Romaniuk K.: Wiara w zmartwychwstanie. Pusty grób. Pojawienie się zmartwychwstalego, „Attende lectioni” 6 (1981) 1-93.

Rosłon J.: Jak przedstawia się od strony biblijnej sprawa darów Ducha Swiętego? Co to jest grzech (grzech?) przeciwko Duchowi Swiętemu? CT 44: 1974,1 , s. $138-143$.

Scheffczyk L.: Zmartwychwstanie, Warszawa 1984, PAX, ss. 320 (rozdz. - Biblijne podstawy w świetle myśli systematycznej, s. 75-173; $\S$ - Kerygmat zmartwychwstania w Ewangelii św. Łukasza, s. 89-97; $\S$ - Objawienie Ducha Swiętego, s. 210-214; zob. także indeks tekstów biblijnych ( $\mathrm{kk}, \mathrm{Dz})$ s. 306n.).

Scheffczyk L.: Zmartwychwstanie Jezusa - fundamentalna prawda wiary, Com (pol.) 2 (1985) 11-22.

Szymanek E.: Zesłanie Ducha Swiętego. W: Chrystus i Kościół (pod red. F. Gryglewicza), Lublin 1979, RW KUL, s. 93-99.

Szymanek E.: Zmartwychwstanie Chrystusa w nauczaniu św. Pawła, Więź 3 (1977) 9-19.

Trilling W.: Zmartwywchstanie Jezusa. W: Biblia dzisiaj (pod red. J. Kudasiewicza), Kraków 1969, PTT, s. 263-283.

Tomaszewski E.: Pusty grób i chrystofanie jako znaki zmartwychwstania Jezusa z Nazaretu, CS 10 (1978) 149-162.

Wolniewicz M.: Swiadectwo i życie. W: W kręgu Nowego Przymierza, Poznań 1985, Księgarnia św. Wojciecha, s. 205-278 (zwłaszcza s. 205-222). Ziidkow J. I.: O Duchu Swiętym, „Chrześcijanin” 1-2 (1957) 29-31.

\section{Kerygmat Jezusa i apostołów}

Balthasar H. U.: Jezus i przebaczenie, Com (pol.) 5 (1984) 48-61. sS. 85 .

Barclay W.: Jezus Chrystus dzisiaj, Warszawa 1975, Pielgrzym Polski,

Barreau J. C.: Ewangelia dla każdego z nas, Warszawa 1975, PAX, ss. 267 (rozdz. - Ewangelia według świętego Eukasza i jej wielkie tematy, s. $156-171)$.

Bartnik C.: Chrystus kerygmatyczny, CT 52: 1982, 1, s. $61-73$. $28-37$.

Benoit P.: Zmartwychwstanie - fundament wiary, WDr 4 (1974)

Bielaszewski J.: Teologiczna treść perykopy o Marii i Marcie (Ek 10, 38-42). W: Studia z teol. św. Łukasza, s. 158-164.

Biskup M.: Nowy Testament o pokucie i pojednaniu, HD 2 (1983) $86-94$.

Chmiel J.: Agape als Grundbegriffe der christlichen Ethos. Biblisch-strukturelle Analysen, ACr 14 (1982) 295-304.

Chmiel J.: Biblijne podstawy pokuty, RBL 35 (1982) 402-411.

Chmiel J.: Interpretacja Starego Testamentu w kerygmacie apostolskim o zmartwychwstaniu Jezusa. Studium hermeneutyczne, Kraków 1979, PTT, ss. 222 (zwłaszcza rozdz. II - Kerygmat pentekostalny ( $\mathrm{Dz} 2,14-36)$, s. 48-98; rozdz. III - Kerygmat taumaturgiczny (Dz 3, 12-26; 4, 8-12), s. $98-135)$.

Chmiel J.: Tradycja apostolska a redakcja Łukasza w Dziejach Apostolskich, ACr 8 (1976) 125-131.

Cieślik P.: Kerygmat o Jezusie z Nazaretu w kazaniach misyjnych Dziejów Apostolskich, RBL 34 (1981) 113-119.

Comblin J.: Pokój w teologii św. Łukasza, "Gość Niedzielny” 1965, s. $166,172,178,183,189-191$. 
Czerski J.: Pajęcie świętości w trzeciej Ewangelii i Dziejach Apostolskich. W: Studia z teol. św. Łukasza, s. 141-157.

Czerski J.: Pokuta w Ewangelii św. Eukasza, „Studia Teologiczno-Historyczne Sląska Opolskiego" 3 (1973) 173-177.

Daniel S.: Znaczenie wyrażenia ,palec Boży” w Piśmie świętym, RBL 10 (1957) $247-260$.

Dąbrowski E.: Mowa na Areopagu (Dz 17, 22-31). W: Dzieje Apostolskie, s. $534-541$.

Denis H.: Ewangelia i dogmaty, Warszawa 1979, PAX, ss. 163 (rozdz. Ewangelia prawdy i życia, s. $30-58$ ).

Dodd C. H.: Przypowieści o Królestwie, Kraków 1981, Znak, ss. 154.

Duesberg H.: Oświecił ich umysły, żeby rozumieli Pisma, Conc (pol.) $1-10(1966-67) 658-664$.

Filipiak M.: Biblijne podstawy teologii pracy, ŻM 6 (1976) $30-37$.

Filipiak M.: Mesjanizm w Piśmie świętym, ZN KUL 2 (1973) 75-79.

Gerken A.: Teologia Eucharystii, Warszawa 1977, PAX, ss. 278 (rozdz. I - Podstawy biblijne, s. 14-63).

Głowa S.: Owoce chrztu w świetle Objawienia, AK 338 (1965) 165-176.

Grabianka S.: Syn marnotrawny. Ek 15, 11-31, RBL 17 (1964) 109-112.

Grelot P.: Swiat, który ma przyjść, Warszawa 1979, PAX, ss. 147.

Gryglewicz F.: Bogactwo i trudności metafory o Królestwie Bożym w nauczaniu Chrystusa Pana, RBL 16 (1963) 42-48.

Gryglewicz F.: Bóg i jego plan zbawienia w ujęciu św. Łukasza.

W: Studia z teol. św. Łukasza, s. $9-45$.

Gryglewicz F.: Bóg w Ewangelii św. Eukasza. W: Ewangelia wg św. Łukasza, s. $363-374$.

Gryglewicz F.: Chleb, wino i Eucharystia w symbolice Nowego Testamentu, Sprawozdania KUL 15 (1967) 11-13.

Gryglewicz F.: Chleb, wino i Eucharystia w symbolice Nowego Testamentu, Poznań 1968, Księgarnia św. Wojciecha, ss. 147.

Gryglewicz F.: Ewangelie o Jezusie Chrystusie. W: W kręgu Dobrej Nowiny (pod red. J. Szlagi), Lublin 1984, RW KUL, s. 191-231.

Gryglewicz F.: Jezus Chrystus w oczach Ewangelistów, AK 333 (1964) $233-241$.

Gryglewicz F.: Myśl o posłaniu Chrystusa Pana w Nowym Testamencie, RTK 16: 1971, 1, s. 97-112.

Gryglewicz F.: Nauczanie Chrystusa Pana w przypowieściach o robotnikach w winnicy i synu marnotrawnym, RTK 7: 1960, 4, s. 5-20.

Gryglewicz F.: Nowe Prżymierze (fragment pracy pt. Chleb, wino

i Eucharystia w symbolice Nowego Testamentu), RTK 12: 1965, 1, 49-57.

Gryglewicz F.: Praca Ewangelistów nad przypowieściami o robotnikach w winnicy i o synu marnotrawnym, RTK 6: 1957, 2, s. 226-240.

Gryglewicz F.: Problem miłości w Nowym Testamencie, RBL 27 (1974) $257-265$.

Gryglewicz F.: Słownictwo św. Łukasza o Bożym planie zbawienia, RH 3 (1972) 107-108.

Gryglewicz F.: Słownictwo św. Eukasza o grzechu i ich odpuszczeniu, RTK 21: 1974, 1, s. 13-24.

Gryglewicz F.: Teologiczne aspekty Piotrowych przemówien ( $\mathrm{Dz} 2$, $14-36 ; 3,12-26)$, ZN KUL 2 (1969) 23-34.

Gryglewicz F.: Znaczenie grzechu u św. Łukasza. W: Ewangelia wg św. Łukasza, s. $404-419$.

Grzybek S.: Kto jest moim bliźnim, RBL 17 (1964) 311-315.

Górski T.: Agnostos Theos (Dz Ap. XVII, 18-34), RBL 6 (1953) 154-159.

Guillet J.: Jezus Chrystus w naszym świecie, Warszawa 1980, PAX, Ss. 208 . 
Guillet J.: Jezus wczoraj i dziś, Kraków 1982, Wyd. Apostolstwa Modlitwy, ss. 265 (rozdz. I - Boże Narodzenie i oczekiwanie na sprawiedliwośc, s. 17-31; rozdz. IV, § 4-Duch Swięty i ubodzy, s. 73-75; rozdz. V Walki Jezusa Chrystusa, s. 76-89; rozdz. VI - Ubóstwo Jezusa Chrystusa, s. 90-102; rozdz. VII - Posłuszeństwo Jezusa Chrystusa, s. 103-120; rozdz. VIII - Modlitwa ewangeliczna, s. 121-134; rozdz. IX - Modlitwa dziękczynna Syna Bożego, s. 135-151, rozdz. X - Ewangelia i chleb, s. 152-165).

Guillet J.: Uwierzcie Ewangelii, Kraków 1982, Wyd. Apostolstwa Modlitwy, ss. 215 (zob. indeks ( $\mathrm{kk}$ i Dz) s. 208-210).

Haabeck T.: U podstaw wiary, Warszawa 1975, PAX.

Haręzga S.: Eklezjotwórcza funkcja Słowa Bożego według $D_{z}$ 3, 22-23, CT 54: 1984, 3, s. 29-38.

Hergesel T.: Biblijna idea ewangelizacji, CS 11 (1979) 255-271.

Hergesel T.: Glos wołającego na pustyni: przygotowujcie drogę dla Jahwe, CS 5 (1973) 147-155.

Hergesel T.: Moc ewangelizacji, Com (pol.) 6 (1982) 44-59.

Hello E.: Nawrócenie św. Pawła, RBL 6 (1953) 163-166.

Hergesel T.: Ewangelizacja w Biblii. W: W kręgu Dobrej Nowiny, (pod red. J. Szlagi), Lublin 1984, RW KUL, s. 83-98.

Hergesel T.: Motywy uwielbienia Boga w Łukaszowej interpretacji cudów Jezusa - wielkiego proroka, RBL 34 (1981) 263-273.

Herrmann T.: Miłość braterstwa według sw. Jana w świetle ewangelii synoptycznych i św. Pawła, STV 2 (1979) 43-64.

Jankowski A.: Doniosłość Łukaszowej eschatologii indywidualnej, RBI 28 (1975) 216-225.

Jankowski A.: Królestwo Boże w przypowieściach, Poznań 1981, Pallottinum, ss. 176 (zob. skorowidz biblijny, s. 167-168).

Jankowski A.: O biblijnych kategoriach sakramentologii, AR 334 (1964) $269-276$.

Jankowski J.: Przypowieść o synu marnotrawnym w interpretacji encykliki Dives in misericordia. W: Encyklika Ojca Swiętego Jana Pawła II o Bożym miłosierdziu Dives in misericordia - tekst i komentarz, Kraków 1981, PTT, s. $110-116$. $1-12$.

Jankowski A.: Wymiar pneumatologiczny chrystologii, RBL 35 (1982)

Jankowski A.: Znak spod Naim (Ek 7, 11-17), CT 32: 1962, 1-4, s. $1-180$.

Jelonek T.: Postać Mojżesza w Nowym Testamencie, RBL 33 (1973) $107-110$.

Jelonek T.: Zbawcze znaczenie Eukaszowego, dzisiaj”, RBL 26 (1973) $107-112$.

Jóźwiak F.: Znaczenie modlitwy w dziełach św. Eukasza. W: Studia z teol. św. Eukasza, s. 125-140.

Kilmartin J.: Ostainia wieczerza i najnowsze ofiary eucharystyczne w Kościele, Conc (pol.) 6-10 (1969) 561-568.

Kłoczowski J.A .: Jezus Ewangelistów, WDr 12 (1975) 22-23.

Kokot M.: Znaczenie nasienia w Eukaszowej przypowieści o siewcy, CT 43: 1973, 2, s. 77-83.

Kończak A.: Judaistyczne czy uniwersalistyczne idee $w$ nauczaniu Jezusa? W: Studio lectionem facere, s. 87-90.

Kowalczyk A.: Termin ,tajemnica Królestwa Bożego" w świetle tekstów biblijnych i intertestamentalnych, „Studia Gdańskie" 2 (1976) 41-49.

Kowalski S.: „Dobra Nowina” o Jezusie Chrystusie w pierwotnej gminie chrześcijańskiej, „Słowo Powszechne” 24: 1956.

Kudasiewicz J.: Biblijna teologia chrztu, MPWB3 ( 1978) 139-159. 
Kudasiewicz J.: Bóg Ewangelii. W: W kręgu Dobrej Nowiny (pod red. J. Szlagi), Lublin 1984, RW KUL, s. 159-174.

Kudasiewicz J.: Elementy eklezjalne w tekstach ustanowienia Eucharystii, STV 2 (1980) $29-48$.

Kudasiewicz J.: Elementy eklezjalne w tekstach ustanowienia Eucharystii. W: Kościół w świetle Biblii (pod red. J. Szlagi), Lublin 1984, TN KUL, s. $53-65$.

Kudasiewicz J.: Etos chrześcijański. EK 4 (1983) 1196-1202.

Kudasiewicz J.: Historiozbawcza interpretacja tekstów eucharystycznych, RTK 26: 19'79, 4, s. 137-143.

Kudasiewicz J.: ,Jeruzalem deptane będzie przez pogan” (Ek 21, 20-24), RTK 19: 1972, 1, s. 83-92.

Kudasiewicz J.: Jeruzalem - punktem wyjścia misji apostolskiej (Łk 24, 47n.; Dz 1, 8). W: Materiały Kongresu Biblijnego w Krakowie, Kraków 1974, PTT, s. $124-155$.

Kudasiewicz J.: Nazwy Jeruzalem i Jerozolima w użyciu św. Łukasza, RTK 20: 1973, 1, s. 17-36.

Kudasiewicz J.: Miłosierdzie w Ewangeliach. W: Jan Paweł II. Dives in misericordia. Tekst i komentarz, Lublin 1983, RW KUL, s. 69-82.

Kudasiewicz J.: Miłosierdzie w słowach i czynach Jezusa. W: Encyklika Ojca Swiętego Jana Pawła II o Bożym miłosierdziu Dives in misericordia - tekst i komentarz, Kraków 1981, PTT, s. 98-110.

Kudasiewicz J.: Rola Ducha Swiętego w dziejach zbawienia, MPWB 6 (1983) $45-80$.

Kudasiewicz J.: Rola Jeruzalem w Łukaszowej sekcji podróży (Ek 5-19, 27), RTK 16: 1969, 1, s. 17-40.

Kudasiewicz J.: Słowo Jezusa pełne mocy, RBL 33 (1980) 101-105.

Kudasiewicz J.: Znaczenie Jeruzalem w czasie działalności galilejskiej Jezusa w Ek 4, $14-9,50$, RTK 17: 1970, 1, s. 43-59.

Kwas A.: Bóg Ojciec w Nowym Testamencie, RBL 35 (1982) 186-192.

Kwiatkowski W.: Od Jezusa historii do Chrystusa kerygmatu, STV 2 (1964) $3-30$.

Léon-Dufour X.: „Czyńcie to na moją pamiątkę”, PP 5 (1982) 246-257.

Each J.: Królewska intronizacja Jezusa, Syna Dawida, w mowie św. Pawła w Antiochii Pizydyjskiej (Dz 13, 16-41). W: Królestwo Boże W Piśmie świętym (pod red. S. Eacha i M. Filipiaka), Lublin 1976, RW KUL, s. $177-185$.

Langkammer H.: Najstarsza soteriologiczna interpretacja śmierci Jezusa. W: Biblia - księga życia Ludu Bożego (pod red. S. Eacha i M. Filipiaka), Lublin 1980, RW KUL, s. 129-140.

Langkammer H.: Oryginalnośé Jezusowego przepowiadania. W: Studio lectionem facere, s. $78-86$.

Langkammer H.: Początki chrystologii Nowego Testamentu, Lublin 1977, RW KUL, ss. 70 (s. 9-11, 16, 19, 21, 39, 48, 52-60, 63-56).

Langkammer H.: Slowa Jezusa o piciu z winnego krzewu w Królestwie Bożym na tle przekazów ustanowienia Eucharystii (Mk 14, 25; モk 22, 15-18), MPWB 3 (1978) 191-196.

H. Langkammer H.: Syn Człowieczy w Ewangeliach synoptycznych, CS 4 (1972) $77-93$.

Langkammer $\mathrm{H}$.: Teologiczny aspekt Boga w Ewangeliach synoptycznych, CS 5 (1973) 109-115.

Langkammer H.: U podstaw chrystologii Nowego Testamentu, Wrocław 1976, Wyd. Wrocławskiej Księgarni Archidiecezjalnej, ss. 294 (s. 11-16, 25, $30,40-44,46,73,76-79,93-100,119,124-131,193-195,201,212-243$, $262-276,280-284,288$ ).

Langkammer H.: Wiara w Nowym Testamencie, RTK 22: 1975, 3, s. $23-31$. 
Langkammer H.: Zagadnienia autentycznego brzmienia słów konsekracji, RBL 28 (1975) 101-107.

Łach J.: Jezus, Syn Dawida. Studium egzegetyczno-teologiczne, Warszawa 1973, ATK, ss. 221 (cz. I, rozdz. I - „Syn Dawida” w najstarszych formułach wiary, § $3-\mathrm{Dz} 2,25-36$, s. $51-54 ; \S 4-\mathrm{Dz} 13,23$. 32-37, S. $54-57$; $\S 5-\mathrm{Dz} 15,16-18$, s. 57-59; rozdz. II - „Syn Dawida” w opisach publicznej działalności Jezusa u synoptyków, s. 60-117; cz. II, rozdz. I - Geneologia Jezusa, ,Syna Dawida”, § 2 - Łk 3, 23-38, s. 137-138;

$\S 3$ - Historyczna wartość geneologii Jezusowych, s. 138-147).

Each J.: Przypowieść o synu marnotrawnym obrazem miłosierdzia ucieleśniającego sprawiedliwość, Com (pol.) 2 (1981) 87-98.

Łach S.: „Odpuść nam nasze winy”. W: Biblia - księga życia Ludu Bożego (pod red. S. Eacha i M. Filipiaka), Lublin 1980, RW KUL, s. $121-128$.

Masters C.: Boże, gdzie jesteś, Poznań-Warszawa 1978, Pallottinum, ss. 204 (rozdz. XI - Od ,Ewangelii" do czterech Ewangelii, s. 123-131; rozdz. XIII - Przypowieści: odkryć Boży sens w tym co ludzkie, s. 151159; rozdz. XIV - Cuda Pana Jezusa: zapowiedź czekającej nas przyszłości, s. 160-171; rozdz. XV - Przemienienie Pana Jezusa: znaczenie przełomów w życiu, s. 172-181; rozdz. XVI - Wolność chrześcijanina: pluralizm w sposobie przeżywania tej samej wiary w Jezusa Chrystusa, s. 182-190; rozdz. XVII - Wiara w zmartwychwstanie: „Jeśli Bóg jest z nami, któż może będzie przeciw nam?", s. 191-202).

Moysa S.: Słowo zbawienia, Kraków 1974, Znak, ss. 272.

Muszyński H.: Bóg a zło w Piśmie świętym, CT 49: 1979, 2, s. 23-47.

Najder K.: Jak Jezus mówił kazania? (Psychologiczny rozbiór kazania Chrystusa). Ew. Łuk. 12 rozdz., „Droga” 3 (1947) 4-8.

Odzimek A.: Eukaszowy kerygmat o Jezusie Męczenniku, RBL 33 (1980) 68-79.

Ordon H.: Znaczenie określenia „Duch Jezusa” w Dz 16, 7. W: Studia $\mathrm{z}$ teol. św. Eukasza. s. 72-79.

Paciorek A.: Chrystus a świat - afirmacja czy negacja. W: Studio lectionem facere, s. 173-175.

Paściak J.: Biblijny obraz Chrystusa Króla, RBL 25 (1972) 169-189.

Romaniuk K.: „Być dzieckiem” według Biblii, Com (pol.) 3 (1985) 3-17.

Romaniuk K.: Eschatologia (w NT), EK 4 (1983) 1109-1111.

Romaniuk K.: Eucharystia w przekazach biblijnych, AK 445 (1983) $335-348$.

Romaniuk K.: „Idąc na cały świat...”. W: Z zagadnień kultury chrześcijańskiej, Lublin 1973, TN KUL, s. 129-136.

Romaniuk K.: Małżeństwo i rodzina w Biblii, Katowice 1983, Księgarnia św. Jacka, ss. 171 (cz. II, rozdz. I - Nauczanie Jezusa, s. 64-104).

Romaniuk K.: Pokuta a pojednanie w Nowym Testamencie, CT 48: 1978 , 4, s. $15-34$.

Rubinkiewicz R.: Nowotestamentalna idea przepowiadania, „Seminare” 3 (1978) $37-59$.

Rubinkiewicz R.: Postać Jezusa w drugiej mowie Piotra (Dz 3, 12-26), MPWB 5 (1982) 109-134.

Salguero J.: Biblijny sens pustyni, WDr 7 (1976) 25-35.

Santorski A.: Pojęcie grzechu według Ewangelii i w świadomości współczesnego człowieka, HD 3 (1980) 182-184.

Schürmann H.: Słowa Jezusa przy ostatniej wieczerzy w świetle wykonywanych przy nich czynności, Conc (pol. 1-10 (1968) 589-597.

Stachowiak L.: Modlitwa w Piśmie świętym, AK 228 (1963) 299-309.

Stanley D. M.: Slowo Boże światłością i drogą, Kraków 1975, Wyd. Apostolstwa Modlitwy, ss. 388 (rozdz. XII - Dobra Nowina Bożego Narodzenia, s. 145-154; rozdz. XVII - Dwunastu - powołania i rozesłanie, 
s. 197-207; rozdz. XVIII - Jezus karmi rzeszę, s. 209-219; rozdz. XIX Matka Najświętsza w życiu pierwotnego Kościoła, s. 220-229; rozdz. XX Jezus „drogą" do Ojca, s. 231-244).

Stanley D.: Nauczanie Kościola pierwotnego i jego tradycyjny schemat, Conc (pol.) 1-10 (1966-67) 605-612.

Stefaniak Z.: Przypowieści o modlitwie u św. Łukasza, RBL 8 (1955) $84-107$.

Strus A.: Funkcja obrazu w przekazie biblijnym: obraz winnicy w Iz 5, 1-7 i w Ewangelii, STV 2 (1977) 25-54.

Szlaga J.: Apokaliptyczne „co ma nastąpić niebawem” a oczekiwanie na paruzję, RBL 28 (1975) 230-234.

Szlaga J.: Główne tematy w ewangelii Jezusa Chrystusa, RBL 32 (1979) $123-139$.

Szlaga J.: Jezus o pracy i dobrach materialnych. W: Biblia - ksiega Ludu Bożego (pod red. S. Eacha i M. Filipiaka), Lublin 1980, RW KUL, s. $103-110$.

Szlaga J.: Pokuta, nawrócenie i pojednanie według Pisma św., MPWB 6 (1983) $25-43$.

Szlaga J.: Symbolika miecza u Łk 22, 35-38. W: Studia z teol. św. Łukasza, s. 165-171.

Szlaga J.: Ewangelia Jezusa Chrystusa. W: W kręgu Dobrej Nowiny (pod red. J. Szlagi), Lublin 1984, RW KUL, s. 175-190. -162 .

Szymanek E.: Postawa służebna w Piśmie świętym, HD 3 (1967) 156-

Szymanek E.: Wiara w dziełach św. Łukasza, HD 3 (1973) 203-208.

Tresmontant C.: Jezus naucza, Warszawa 1973, PAX, ss. 251 (s. 49, 53, $59,71,83,95,98,108-111,113,118-119,123-124,128-130,144-151,158$, $166,170,180,195-201,208-220,241)$.

Wajszczuk E.: Funkcje wychowawcze Chystusa w Ewangeliach, CT 40: 1970, 2, s. $61-76$.

White E. G.: Przypowieści Chrystusa, Warszawa 1959, Znaki Czasu, ss. 273.

Wodecki B.: Idea misyjna w Piśmie świętym Nowego Testamentu, AK 360 (1969) $24-35$.

Wolniewicz M.: Galilejska misja Apostołów, „Msza święta” 1965, s. $135-136$.

Wolniewicz M.: Grzesznica bezimienna (Ek 7, 36-50), „Msza święta” 1964 , s. $5-6$.

Wolniewicz M.: Kazanie na Górze, „Msza święta” 1964, s. 10—15.

Wolniewicz M.: Nauczał w przypowieściach (Łk 8, 1-21), „Msza święta" 1965 , s. $12-15$.

Wolniewicz M.: Nauczanie Jezusa. W: W kręgu Nowego Przymierza, Poznań 1985, Księgarnia św. Wojciecha, s. 69-204.

Wolniewicz M.: Prawdziwe oblicze Mesjasza (Łk 9, 10-45), „Msza święta" 1965, s. 164-169.

Zawiszewski E.: Jezus historii i Chrystus kerygmatu, SPelp 10 (1975) $63-67$.

Ziółkowski Z.: Chrystus Ewangelii i historii, ŻM 9 (1974) 10-18. $207-215$.

Żoń A.: Eklezjologiczny sens terminu ,droga" w Dz 9, 2, RBL 17 (1964)

\section{PIERWOTNA WSPOLNOTA CHRZESCIJAŃSKA}

Ateny i Efez w czasach apostoła Pawła, „Strażnica Ewangeliczna 15 (1960) $131-133$.

Balthasar H. U.: Modlitwa chrześcijańska, Com (pol.) 4 (1985) 17-28.

Bartnik C.: Eklezjologia, EK 4 (1983) 773-781. 
Bilhmeyer K., Tüchle H.: Starożytność chrześcijańska. W: Historia Kościoła, Warszawa 1971, Wyd. SS. Loretanek, s. 43-180.

Bogacki H.: Charyzmatyczna struktura Kościoła pierwotnego, CT 41: 1971 , 2, s. $43-52$.

Brox N.: Profile chrześcijaństwa w najdawniejszej jego epoce, Conc (pol.) 1-10 (1971) 308-319.

Bulanda E.: Narodziny chrześcijaństwa, AK 338 (1965) 129-137.

Chmiel J.: Biblijne pojęcie agapē jako model etyczny, RBL 30 (1977) 214-216.

Chmiel J.: Pojęcie i rola kerygmatu w pierwotnym Kościele, RBL 30 (1980) $58-68$.

Daniel-Rops H.: Kościół pierwszych wieków, Warszawa 1969, PAX, s. 701 (szczególnie s. 5-115).

Danielou J., Marrou H. J.: Historia Kościoła, Warszawa 1984, PAX, t. 1, ss. 420 (rozdz. I - Kościół pierwotny, s. 21-30; rozdz. II - Kościół poza Jerozolimą, s. $31-39$; rozdz. III - Kryzys judeochrześcijaństwa, s. $40-47)$.

Dąbrowski E.: Judeo-chrześcijanie i helleniści ( $\mathrm{Dz}$ 6, 1-6). W: Dzieje Apostolskie, s. 486-490.

Dąbrowski E.: Pobyt św. Pawła na Malcie (Dz 28, 1-11). W: Dzieje Apostolskie, s. $576-579$.

Dąbrowski E.: Prześladowanie chrześcijaństwa i śmierć Heroda Agryppy I (Dz 12, 1-25). W: Dzieje Apostolskie, s. 509-514.

Dąbrowski E.: Rzymska podróż św. Pawła. W: Studia biblijne i archeologiczne, Poznań 1963, Księgarnia św. Wojciecha, s. 15-48.

Dąbrowski E.: Sobór Jerozolimski (Dz 15, 1-29). W: Dzieje Apostolskie, s. $515-525$.

Dąbrowski E.: Spotkanie św. Pawła z królem Agryppą II i z siostrą jego Bereniką ( $\mathrm{Dz} 25,13-26,32$ ). W: Dzieje Apostolskie, s. 564-575.

Dąbrowski E.: Sw. Pawel a hellenizm, Znak 3 (1948) 361-364.

Dąbrowski E.: Tzw. wspólnota dóbr w pierwotnym chrześcijaństwie (Dz 2, 44-45; 4, 32. 34-35). W: Dzieje Apostolskie, s. 480-485.

Dodd C. H.: Założyciel chrześcijaństwa, Kraków 1983, Znak, ss. 157 (s. $21-23,27-28,62,90,95,128,130,139,153-155)$.

Dzialalność Apostołów, „Sługa Zboru” 5 (1962) 1-44.

Ehrlich E.: Problemy kobiet w Piśmie świętym, Znak 4 (1976) 463-473.

Gasbarri P.: Trasa podróży św. Pawla do Rzymu i na drodze Appijskiej. W: Studia biblijne i archeologiczne, Poznań 1963, Księgarnia św. Wojciecha, s. 69-74.

Godlewski M.: Pierwszy Kościół w Atenach (Obrazek historyczno-literacki na marginesie Dziejów Ap. r. 17), RBL 6 (1953) 147-154.

Grelot P.: Dzień Pański, Com (pol.) 3 (1982) 5-16.

Gryglewicz F.: Droga, EK 4 (1983) 214-215.

Gryglewicz F.: Eucharystia, EK 4 (1983) 1239-1241.

Gryglewicz F.: Spoleczny charakter Modlitwy Pańskiej, RBL 6 (1953), $207-219$.

Gryglewicz F.: Swiętość wiernych w Nowym Testamencie. W: Drogi świętości (pod red. W. Słomki), Lublin 1980, RW KUL, s. 9-27.

Górski K.: Sobory w dziejach Kościoła, AK 321 (1962) 20-29.

Hergesel T.: Moc ewangelizacji, Com (pol.) 6 (1982) 44-59.

Holstein H.: U początków wspólnoty chrześcijańskiej, Warszawa 1981, PAX, ss. 106.

Jankowski A.: Biblijna teologia przymierza, Katowice 1985, Księgarnia św. Jacka, ss, 164 (zwłaszcza rozdz. III - Dziejowa realizacja Nowego Przymierza, \& II. 1 - Pozytywna ocena pism Eukaszowych, s. 76-78; III. 2 - Eucharystyczna ,pamiątka” Nowego Przymierza, s. 102-121; rozdz. IV - Miejsce Nowego Przymierza w dziejach zbawienia, s. 122-145). 
Jankowski A.: Myśl Boża o Kościele objawiona w Piśmie świętym, AK 324 (1863) $1-18$.

Jankowski A.: „Sludzy slowa” (Ek 1, 2), RBI, 32 (1979) 58-60.

Jankowski A., Romaniuk K.: Kapłaństwo w Piśmie świętym Nowego Testamentu, Katowice 1972, Księgarnia św. Jacka, ss. 298 (cz. III, rozdz. I Kolegium Dwunastu oraz uczniowie i Apostołowie Pańscy według czterech Ewangelii, s. 113-142; rozdz. II - Duchowość Apostolów według wymagan Jezusa, s. 142-178; rozdz. III - „Swiadkowie zmartwychwstania" - obraz posługi w Dziejach Apostolskich, s. 179-186).

Javierre A.: Sukcesja apostolska, Conc (pol.) 1-10 (1968) 164-171.

12,15 .

J. B.: Sobór Apostolski w Jerozolimie, „Znaki Czasu”. 12 (1963) 11-

Jelinek E.: Powstanie Kościoła, „Jednota” 1961, s. 106-108.

Jelinek E.: Prześladowanie chrześcijan, ,Jednota” 1960, s. 242-244.

Jelinek E.: Prześladowania chrześcijan, ,Jednota” 1960, s. 242-244.

Jelinek E.: Rzymskie katakumby i grób ap. Piotra, „Jednota” 1961, s. $31-34$.

Jelinek E.: Sladami apostoła przez Azję Mniejszą, „Jednota” 1961, s. $53-56$.

Jelinek E.: Z dziejów pierwotnego Kościoła, rzymski synkretyzm religijny, ,Jednota” 1960, s. 159, 195-197.

Jelinek E.: Zwycięstwo Kościoła, „Jednota” 1961, s, :194-196.

Jelinek E.: Życie zbiorowe pierwszych chrześcijan, „Jednota” 1960, s. $221-224$.

Jelonek T.: Eucharystia i Kościół. Aspekt biblijny, RBL 33 (1980) $280-284$.

Jóźwiak F.: Życie duchowe pierwotnej wspólnoty chrześcijańskiej, AK 398 (1975) $424-438$.

Klawek A.: Sw. Pawel przybywa do Europy, RBL 18 (1965) 175-180.

Klinger W.: Sw. Paweł Apostoł a obszar Macedonii i Hellady, RBL 8 (1955) 195-198.

Kołodziej W.: Działalność misyjna Apostołów w świetle Dziejów Apostolskich, ,Jedność" 1 (1948) 119-121.

Kopeć E.: Spotkanie św. Pawła z Chrystusem, ZN KUL 3 (1960) 45-60.

Kornasiewicz W. M.: Początki chrześcijaństwa, „Ład” 44: 1985.

Kornatowski W.: Ewangeliczna etyka społeczna i jej realizacja w pierwszych gminach chrześcijańskich, żM 3 (1966) 102-119.

Kotula K.: Rola zboru w Antiochii w początkach chrześcijaństwa, „Strażnica Ewangeliczna” 10 (1955) 149-151.

Kowalski S.: Pierwsza gmina chrześcijańska w Tessalonice, „Słowo Powszechne" 215: 1955.

Kudasiewicz J.: Lud Boży, AK 340-341 (1965) 276-286.

Kudasiewicz J.: Chrzest, EK 3 (1979) 352-355.

Kuras J.: Dwunastu, EK 4 (1983) 406-407.

Krasiński J.: Eklezjalny i biblijny aspekt sakramentu pojednania, HD 2 (1983) $94-102$.

Langkammer H.: Uczniowie, grupa Dwunastu, Apostołowie, STV 2 (1976) $67-84$.

Langkammer H.: „Credo” pierwatnych Kościołów: Najstarsze chrystologiczne wyznania wiary, CT 46: 1976, 3, s. 43-49.

Langkammer H.: Jezus u podstaw Kościoła. W: Kościół w świetle Biblii (pod red: J. Szlagi), Lublin 1984, TN KUL, s. 37-51.

Langkammer H.: Oczekiwanie przyjścia „Pana”. „Syna Człowieczego”

w najstarszych gminach chrześcijańskich, AK 376 (1971) 92-104.

Lohfink G.: Dawidowe kuszenie Kościoła, „Novum” 7 (-1979) 22-33.

Lorenzo de Lorenzi D.: Przybycie św. Pawla do Rzymu. W: Studia biblijne i archeologiczne, Poznań 1963, Księgarnia św. Wojciecha,.s. 49-67. 
Each J.: Katechese über die Kirche von Jerusalem in der Apostelgeschichte $(2,42-47 ; 4,32-35 ; 5,11-16)$, CT $\mathrm{nr}$ specjalny (1982) 141-154.

Łach J.: Modlitwa i wspólnota (Dz 2, 42-47), Com (pol.) 4 (1985) 60-66.

Each J.: Rola gminy jerozolimskiej w pierwotnym Kościele (Dz 2, $42-47 ; 4,32-35 ; 5,12-16)$. W: Scrutamini Scripturas, Kraków 1980, PTT, s. $84-98$.

Maroń F.: Założenie Kościoła, „Gość Niedzielny” 33: 1956.

Michelis Z.: Powstanie i historia biblijnego diakonatu, „Strażnica Ewangeliczna" 8 (1953) 38-39.

Milik K.: Z historii księgi Kościoła. Sobór Apostolski w Jerozolimie ok. r. 50, „Przewodnik Katolicki” 1963, s. 251-252.

Młotek A.: Pismo święte w życiu pierwotnych chrześcijan, RBL 30 (1977) $310-323$.

Muszyński H.: Biblijne korzenie modlitwy, AK 445 (1983) 335-348.

Nagy S., Zuberbier A.: Dlaczego kolegializm? Znak 9 (1964) 1098-1113.

Nagy S.: Prezbiterzy w pierwotnej gminie jerozolimskiej, RTK 8: 1961, 1, s. $5-22$.

Nagy S.: Hierarchia kościelna w okresie misyjnej działalności św. Pawła, RTK 11: 1964, 1, s. 55-79.

Nawroczyński B.: Eros - agape - caritas. Poglądy na miłość w świecie helleńskim i wśród chrześcijan, „Sprawozdania Towarzystwa Naukowego Warszawskiego, Wydział II" 41 (1948) 8-13.

Ordon H.: Cezarejska decyzja Piotra. Rozważanie literacko-teologiczne nad perykopą o chrzcie Korneliusza (Dz 10, 1-11. 18), „Summarium” 1 (1978) $51-62$.

Ordon H.: U progu uniwersalizmu Kościoła. Perykopa o chrzcie pierwszych pogan $(\mathrm{Dz} 10,1-11,18)$ w historiozbawczej perspektywie Eukasza. W: Kościół w świetle Biblii (pod red. J. Szlagi), Lublin 1984, TN KUL, s. $73-81$.

Paciorek A.: Rola Piotra w Kościele pierwotnym. W: Kościól w świetle Biblii (pod red. J. Szlagi), Lublin 1984, TN KUL, s. 67-72.

Pielachowski K.: Sw. Paweł w Atenach, „Msza święta” 1981, s. 67-68.

Pielachowski K.: Sw. Paweł w Koryncie, „Msza święta” 1981, s. 92-93.

Poniatowski Z.: Pierwotne chrześcijaństwo. W: Zarys dziejów religii, Warszawa 1964, Iskry, s. 495-547.

Przepiórka B.: Gdzie i kiedy powstała nazwa „chrześcijanie”? HD 3 (1963) $151-154$

Pytel J.: Pojęcie gościnności w literaturze biblijnej i greckiej, RBL 30 (1977) $172-181$.

Rigaux B.: Dwunastu Apostołów, Conc (pol.) 1-10 (1968) 158-164.

Romaniuk K.: Soteriologia św. Pawła, Warszawa 1983, ATK, ss. 318 (cz. II, rozdz. II - Słudzy Kościoła, s. 214-250).

Rosłon J.: „Impositio manuum" w Dziejach Apostolskich, RBL 9 (1957) $102-114$.

Santorski A.: Zarys traktatu o Eucharystii wedlug tekstów Nowego Testamentu, HD 4 (1980) 259-264. $180-184$

Smereka W.: Początki chrześcijaństwa wśród pogan, RBL 18 (1965)

Stępień J.: Apostolstwo w ujęciu biblijnym, RBL 26 (1973) 280-289.

Stępień J.: Eklezjologia św. Pawła, Poznań 1972, Księgarnia św. Wojciecha, ss. 400 (cz. IV - Organizacja pierwotnego Kościola, s. 285-372).

Stępień J.: Teologia sw. Pawła, Warszawa 1979, ATK, ss. 542 cz. IV Organizacja pierwotnego Kościola, s. 441-522).

Szlaga J.: Ekklesia, EK 4 (1983) 768-770.

Szlaga J.: Ku wspólnocie przez wiarę. Refleksje teologiczno-biblijne, Znak 4 (1977) 403-416.

Szymanek E.: Z Jerozolimy do Rzymu, „Msza święta” 1963, s. 8-10. 
Ujda J.: Sw. Paweł w Atenach. Pierwsze spotkanie się młodego chrześcijaństwa ze starożytną myślą helleńską, „Głos Katolicki” 2 (1954) 17, 21.

Vinatier J.: Kobieta w Kościele, Warszawa 1976, PAX, ss. 142 (zwłaszcza s. $96-125$ ).

Voste J. M.: Concilium Hierosolymitanum, Act. Ap. 15, 1-15, CT 31: 1961,4 , s. $153-189$.

Vuilleumier J.: Religia Apostołów, „Znaki Czasu” 5 (1950) 6-12. Ss. 441.

White E. G.: Działalność Apostolów, Warszawa 1961, Znaki Czasu,

Wilkowski S.: Początki chrześcijaństwa według R. Bultmanna, „Kuźnica Kapłańska" 10 (1956) 3-5, 8.

Wolfram K.: Chrześcijaństwo apostolskie, RT 4 (1962) 207-222.

Wolfram K.: Metropolia chrześcijańska w Antiochii (Jej geneza i początkowa faza dziejów), RT 6 (1964) 105-146.

Wolfram K.: Metropolia chrześcijańska w Jerozolimie - jej geneza i początkowa faza dziejów, RT 5 (1963) 311-334.

Wolfram K.: Składowe elementy życia religijno-etycznego w metropolii jerozolimskiej, RT 7 (1965) 156-212.

Wolfram K.: Wspólnota życiowa metropolii jerozolimskiej. W: Księga jubileuszowa z okazji 70-lecia urodzin ks. Jana Szerudy, Warszawa 1959, ChAT, s. 123-135.

Zipfel M.: Historyczne i teologiczne podstawy Kościoła według Nowego Testamentu, ,Strażnica Ewangeliczna" 8 (1953) 256-259, 295-297.

\section{POSTACIE BIBLIJNE}

Aleksandrowicz B.: Zycie wewnętrzne św. Pawła i św. Franciszka z Asyżu, AK 326-327 (1963) 260-265.

Barbagli P. P.: Swięty Józef w Ewangelii. W: Józef $z$ Nazaretu, Krakbw 1979, Wyd. OO. Karmelitów Bosych, t. 2, s. 5-59.

Dawidziuk J.: Poglądy O. Culmanna na prymat Piotra w świetle niektórych wypowiedzi Dziejów Apostolskich i Listu do Galatów, CT 37:1967, 2 , s. $67-81$.

Dąbrowski E.: Barabasz w historii i legendzie. W: Glossy i odkrycia biblijne, Warszawa 1954, PAX, s. 185-195.

Dąbrowski E.: Dzieje Pawła z Tarsu, Warszawa 21953, PAX, ss. 685.

Dąbrowski E.: Nawrócenie św. Pawła według współczesnej krytyki biblijnej (Dz 9, 1-19;22, 4-19; 26, 9-18). W: Dzieje Apostolskie, s. 495-509.

Dąbrowski E.: Problem życia Maryi w biblistyce wspólczesnej, HD 6 (1957) $837-846$.

Dąbrowski E.: Proces św. Pawła w świetle dokumentów. W: Dzieje Apostolskie, s. 550-563.

s. $491-497$.

Dąbrowski E.: Szymon Mag (Dz 8, 4-25). W :Dzieje Apostolskie,

Dąbrowski E.: Sw. Paweł, życie i pisma, Poznań 21952, Pallottinum, ss. 336 .

Dąbrowski E.: Wniebowzięcie Matki Bożej w świetle Pisma św., AK 225 (1947) $417-426$.

Dybowski M.: „Noc ciemna” świętego Józefa, AK 323 (1962) 234-240.

Filas F.: Swięty Józef - czlowiek Jezusowi najbliższy, Kraków 1979, Wyd. Apostolstwa Modlitwy.

Galot J.: Swięty Józef. W: Józef z Nazaretu, Kraków 1979, Wyd. OO. Karmelitów Bosych, t. 1, s. 183-310, zwłaszcza 203-274.

Gedeon J.: Zywot św. Piotra w świetle tradycji i Pisma świętego, „Znaki Czasu" 10 (1949) 22-25.

Gnutek W.: Pawel z Tarsu apostol Jezusa Chrystusa i pisarz natchnio- 
ny. Zarys chronologii życia i działalności apostolskiej i pisarskiej, RBL 18 (1965) 142-151.

Grabska S.: Matka Boża Ewangelistów, Znak 3 (1969) 349-364.

Gryglewicz F.: Barabasz, EK 2 (1976) 2.

Gryglewicz F.: Błogosławiona przez wszystkie narody Matka Boża w Nowym Testamencie, Częstochowa 1984, Częstochowskie Wyd. Diecezjalne „Regina Paloniae”, ss. 85.

Gryglewicz F.: Obraz duchowości Najświętszej Maryi Panny. W:

U boku Syna (pod red. J. Szlagi), Lublin 1984, RW KUL, s. 129-137:

Gryglewicz F.: Ryby i rybacy Tyberiackiego Jeziora, RBL 2 (1949) $382-405$.

Gryglewicz F.: Uczeni i Jezus, "Tygodnik Powszechny" 47:1950.

Hergesel T.: Legenda o Józefie cieśli w kulcie oblubieńca Matki Bożej, RBL 27 (1974) 221-230.

Jankowski A.: Maryja - biblijną syntezą powołania kobiety, Znak 4 (1976) 476-486.

Jankowski A.: Matka Mesjasza pierwowzorem Kościola. Nowe drogi i próby syntez mariologii biblijnej, AK 333 (1964) 209-219.

Jarząbek F.: Pierwsze świadectwo (Szczepan - przypis wł.), KDW. 46 (1963) 26-29. $67-75$.

Kaczmarski H. J.: Kobiety w Dziejach Aposțolskich, „Novum” 10 (1976)

Kamieńska A.: Niewiasty biblijne, WDr 5 (1980) 56-77.

Kędziora J.: Szymon syn Jony. Portret człowieka, Kraków 1948.

Klawek A.: Ekwiwalent semicki „Ave Maria”, „Sprawozdania PAU” 5 (1951) $429-430$. 402.

Klawek A.: Etymologia imienia Maria, „Sprawozdania PAU” 48 (1947)

Klawek A.: Etymologia imienia Maria, PS 1: (1948) 176-184.

Klawek A.: Imię Maria, RBL 4 (1951) 56-58.

Kowalski S.: Niewiasty korynckie, "Słowo Powszechne" 24: 1956.

Kudasiewicz J.: Marta i Maria (Ek 10, 38-42). W: Kontemplacja i działanie (praca zbior. pod red. W. Słomki), Lublin 1984, RW KUL, s. 25-43.

Kudasiewicz J.: Matka naszego zawierzenia, WDr 8 (1980) 45-54.

Lechicki C.: Diakon Szczepan, „Pielgrzym Polski” 1949, s. 29-31.

Each J.: Bracia Jezusa, STV 2 (1973) 257-264.

Martelet "B:: Józef z Nazaretu. Mąż ufności. W: Józef z Nazaretu, Kraków 1979, Wyd. OO. Karmelitów Bosych, t. 1, s. 21-181 zwłaszcza $21-114$.

Nicolas A., Dąbrowski E.: Życie Maryi Matki Bożej, Poznań ${ }^{\mathbf{3} 1964,}$ Księgarnia św. Wojciecha, ss. 328 (rozdz. IV - Problem Maryi w Ewangeliach, s. 53-72; rozdz. V - Boży plan, s. 73-79; rozdz. VI - Narodzenie Maryi: głosy biblijne i pozabiblijne, s. 80-90; rozdz. VII - W cieniu świątyni, s. 91-95; rozdz. IX - Ave Maria, s. 103-120; rozdz. X Magnificat, s. 121-135; rozdz. XI - „Wydany zostal dekret przez cesarza Augusta", s. 136-144; rozdz. XII - Cicha noc... święta noc..., s. 145-157; rozdz. XIII - W świątyni jerozolimskiej: Ofiara matki, Spotkanie, s. 158-171; rozdz. XIX - Maryja w czasie publicznej działalności Jezusa, s. 228-237; rozdz. XXI - Maryja a zmartwychwstanie i wniebowstąpienie Chrystusa, s. 256-264; rozdz. XXII - Maryja w wieczerniku wśród Apostołów i wiernych s. 265-274; rozdz. XXIII - Wniebowzięcie s. 275-298).

Niemczyk J.: Sw. Pawel - apostol pogan, RT 6 (1964) 64-79. s. $27-28$.

Oferyński K.: Uczniowie Chrystusa, "Znaki Czasu" 5 (1948) 5-7; 6,

Postacie biblijne, Bytom 31959 , Strażnica Ewangeliczna, ss 187.

Prokulski W.: Sw. Piotr - Apostol Chrystusa; RBL 18 (1965) 129-142.

Romaniuk K.: Duchowość apostolów według wymagań Chryștusa. W: 
Powołanie człowieka. Ku odnowie życia wewnętrznego, Poznań 1972, Pallottinum, s. $143-174$.

Romaniuk K.: Czy i do jakiego stopnia Szaweł był przygotowany do przyjęcia chrześcijaństwa? W: Studio lectionem facere, s. 104-106.

Romaniuk K.: Powołanie w Biblii, Katowice 1975, Księgarnia św. Jacka, ss. 164 (cz. II - Powołanie w Nowym Testamencie, s. 55-159).

Sotowski W.: „Maryja przechowywała wszystkie te słowa w sercu swoim". W: Studia z teol. św. Łukasza, s. 88-104.

Stachowiak L.: Prorocy - słudzy słowa, Katowice 1980, Księgarnia św. Jacka, ss. 285 (rozdz. VIII - Prorocy a Nowy Testament, s. 259-276).

Steimann J.: Paweł z Tarsu, Kraków 1965, Znak, ss. 237.

Stramare P. T.: Syn Józefa z Nazaretu. Problemy dotyczące dzieciństwa Jezusa. W: Józef z Nazaretu, Kraków 1979, Wyd. OO. Karmelitów Bosych, t. 2, s. $61-124$.

Szlaga J.: "Oto moja matka i moi bracia". W: U boku Syna (pod red. J. Szlagi), Lublin 1984, RW KUL, s. 95-107.

Szreder F.: Swięty Józef a zjednoczenie hipostatyczne, RBL 27 (1974) $215-220$.

Tronina A.: Maryja - stolica mądrości. W: U boku Syna (pod red. J. Szlagi), Lublin 1984, RW KUL, s. 55-63.

Widła B.: Apostolska postawa św. Pawla jako dawanie świadectwa o Chrystusie, STV 2 (1975) 81-103.

Winiarski K.: Matka Najświętsza w Piśmie świętym. W: Gratia Plena. Studia teologiczne o Bogurodzicy, Poznań 1965, Księgarnia Wojciecha, s. $31-58$.

Wolniewicz M.: Swięty Józef w Ewangelii, AK 414 (1978) 18-31.

\section{PRACE PORÓWNAWCZE}

Bartnicki R.: Pascha żydowska a chrześcijańska ofiara eucharystyczna, STV 1 (1980) 97-124.

Dąbrowski E.: Odkrycia w Qumran nad Morzem Martwym a Nowy Testament, Poznań-Warszawa-Lublin 1960, Księgarnia św. Wojciecha, ss. 172 (rozdz. VI - Odkrycia w Qumran a chrześcijaństwo, s. 73-119).

Dąbrowski E.: Organizacja pierwotnego Kościoła w świetle dokumentów z Qumran. W: Dzieje Apostolskie, s. 475-485.

Gryglewicz F.: Kolegium Dwunastu w Nowym Testamencie i w Qumran. W: Pod tchnieniem Ducha Swiętego, Poznań 1964, Księgarnia św. Wojciecha, s. $209-228$.

Jelonek T.: Streszczenie dzieła Eukaszowego w Liście do Hebrajczyków, ACr 13 (1981) 143-151.

Jóźwiak F.: Obmycia w Qumran a chrzest Jana Chrzciciela, AK 338 (1965) $137-151$.

Jóźwiak F.: Swięty Jan Chrzciciel a Qumran, AK 376 (1971) 123-135.

Kabaj J.: Judeochrystianizm a chrześcijaństwo, „Studia Religiologica” 5 (1980) 23-41.

Langkammer H.: Pawel i Łukasz w swoich treściach teologicznych poglądów. W: Studia z teol. św. Łukasza, s. 204-213.

Pilarczyk K.: Kościół a judaizm wczoraj i dziś, „Ład” 38 : 1985.

Rubinkiewicz R.: Eschatologia Hen 9-11 a Nowy Testament; Lublin 1984, RW KUL, ss. 139 (s. 85, 88-89, 115-116, 118-124).

Rubinkiewicz R.: Sara - matka Izaaka, Maryja - matka Jezusa (Próba odnalezienia typologii $w$ świetle literatury judaistycznej). W: U boku Syna (pod red: J. Szlagi), Lublin 1984, RW KUL, s. 139-149. Szlaga J.: O tzw. sprzecznościach w Ewangelii, AK 441 (1982) 293-303. 


\section{PROBLEMY HISTORYCZNO-FILOZOFICZNE}

Banak J.: Archeologia potwierdza Ewangelię św. Łukasza, „Zorza” $20: 1980$.

Banak J.: Prefekt Judei w czasach Tyberiusza, „Tygodnik Powszechny" $13: 1980$.

Dąbrowski E.: Chronologia Dziejów Apostolskich. W: Dzieje Apostolskie, s. $580-598$.

Dąbrowski E.: Nowy Testament w świetle współczesnych odkryć biblijnych, Znak 12 (1960) 155-179.

Dąbrowski E.: Swiat starożytny u progu chrześcijaństwa. W: Religie świata, Poznań 1957, Księgarnia św. Wojciecha, s. 535-566.

Dąbrowski E.: Życie codzienne w Palestynie w oczach Chrystusa a komentarz do Nowego Testamentu. W: Życie codzienne w Palestynie za czasów Chrystusa, Poznań 1965, PAX, s. V-XXXI.

Dawson C.: Formowanie się chrześcijaństwa, Warszawa 1969, PAX, ss. 287.

Gastpary W.: Historia Kościoła, Warszawa 1967, ChAT, t. 1: Okres starożytny, ss. $173 ;{ }^{8} 1977$, ss. 203.

Gryglewicz F.: Jezus postać historyczna, Lublin 1956, TN KUL, ss. 39.

Kaczorowski A. W.: Sw. Łukasz w roli historyka, "Zorza” $11: 1974$.

Kowalski J. W.: Wczesne chrześcijaństwo. I-X wiek, Warszawa 1985, KAW, ss. 260 (rozdz. I - U źródeł, s. 8-38).

Kudasiewicz J.: Biblia, historia, nauka: rozważania i dyskusje biblijne, Kraków 1978, Znak, ss. 422 (cz. - Ewangelia a historia, s. 247-396; rozdz. I - Fakt istnienia Jezusa - punktem wyjścia Ewangelii, s. 247-271; rozdz. II - Powstanie i historyczna wartość ewangelii, s. 272-314; rozdz. III - Ewangelia dzieciństwa wedlug Mateusza - historia czy legenda, s. 315-333; rozdz. IV - Znaki Jezusa na tle biblijnej i scholastycznej koncepcji cudu, s. $334-363$; rozdz. V - Kazanie na górze - prawem nowego ludu bożego, s. 364-396).

Kulisz J.: Czy Jezus Chrystus jako postać historyczna może być lepiej poznany? CT $55: 1985,1,5-28$.

Markus R. A.: Chrześcijaństwo w świecie rzymskim, Warszawa 1978, PAX, ss. 147 (rozdz. I - Sekta wśród sekt, s. 10-19).

Olszewski D.: Dzieje chrześcijaństwa w zarysie, Katowice ${ }^{21983, ~ K s i e ̨-~}$ garnia sw. Jacka, ss. 290 (cz. I, rozdz. I - W kręgu kultury izraelskiej, s. 13-17; rozdz. II - Pierwsze konfrontacje z cywilizacją grecko-rzymską (do II w.), s. 18-26).

Poniatowski Z.: Jak powstał Kościół? „Roczniki Wolnej Myśli” 1961, s. $146-148$.

Poniatowski Z.: Powstanie i rozwój wczesnego chrześcijaństwa. W: Katolicyzm starożytny, Warszawa 1969, PWN, s. 69-126.

Poniatowski Z.: Pierwotne chrześcijaństwo. W: Zarys dziejów religii, Warszawa 1964, Iskry, s. 495-547.

Poniatowski Z.: U źródeł chrześcijaństwa, „Roczniki Wolnej Myśli" 1961 , s. $139-145$.

Ranowicz A. B.: Wczesne chrześcijaństwo. W: Wybrane zagadnienia $\mathrm{z}$ historii i ateizmu, Warszawa 1954, s. 249-281.

Rode M.: Ideologia społeczna Nowego Testamentu, Warszawa, ChAT, t. 1,1975 , ss. $372 ;$ t. 2 , 1976 , ss. 492 .

Rode M.: Introdukcja do studiów ideologii społecznej Nowego Testamentu, RT 1 (1970) 151-198.

Rode M.: O Kościele Jezusa Chrystusa, Warszawa 1961, Wydawnictwo Literatury Relig., ss. 30 .

Rode M.: Sprawy i mysli gospodarcze w Nowym Testamencie, RT 2 (1971) $115-213$. 
Rode M.: Sprawy i myśli społeczne w Nowym Testamencie, RT 2 (1972) $91-169$.

Rode M.: Sprawy i myśli spoleczne, RT 1 (1973) 87-176.

Romaniuk K.: Krótki zarys historii zbawienia, Poznań 1979, Księgarnia św. Wojciecha, ss. 170 (rozdz. VIII - Jezus z Nazaretu, czyli wypełnienie się proroctw mesjańskich, s. 96-126; rozdz. IX - Historia wprowadzenia w życie nakazu misyjnego Chrystusa, s. 127-145).

Szydelski S.: Chrześcijaństwo a świat starożytny, AK 221 t. 46, s. $221-236,324-329,427-441$.

Umiński J.: Historia Kościoła, Opole 1959, Wyd. Diecezjalne św. Krzyża, t. 1, ss. 672 (rozdz. I - Założenie i rozszerzanie się Kościoła, s. 28-47).

White E. G.: Historia zbawienia, Warszawa 1958, Znaki Czasu, ss. 309. SS. 320 .

Wipper R. J.: Rzym i wczesne chrześcijaństwo, Warszawa 1960, KiW,

Wolniewicz M.: Chrześcijaństwo i judaizm a politeizm w świetle Nowego Testamentu, AK 364 (1969) 226-235.

Żywczyński M.: Kościół i społeczeństwo pierwszych wieków, Warszawa 1985, PAX, ss. 264 (rozdz. II - Jezus Chrystus a stosunki społeczne, s. 35-47; rozdz. III - Stosunki społeczne w gminie jerozolimskiej, s. 48 -66; rozdz. VII - Skład społeczny gmin Pawłowych, s. 111-120).

\section{INNE PUBLIKACJE}

Dembowski W.: Historia biblijna Starego i Nowego Testamentu, Stalirogród 1956, Księgarnia św. Jacka, ss. 296 (cz. Nowy Testament, rozdz. I Narodzenie i młodzieńcze lata Jezusa, s. 133-144; rozdz. II - Pierwszy występ publiczny Jezusa, s. 145-151; rozdz. III - Urząd nauczycielski Chrystusa, s. 152-219; rozdz. IV - Urząd kapłański Chrystusa, s. 220-247; rozdz. V - Urząd królewski Chrystusa, s. 248-254; rozdz. VI — Pierwsze żniwa w królestwie Bożym, s. 255-282).

Drozd J.: Ojcze nasz - modlitwa pańska według współczesnej egzegezy, Katowice 1983, Księgarnia św. Jacka, ss. 216.

Dulles A.: Chrystusa i ewangelia, Warszawa 1971, PAX, ss. 105.

Garden E.: Czy Biblia ma rację? Warszawa 1965, KiW, ss. 301 (rozdz. Czy Judasz Iszkariota był zdrajcą?, s. 181-207; rozdz. - Czy Żydzi zabili Jezusa?, s. 208-233).

Grużewski A.: Quid sibi illud Lucae Evangelistae ,epistata” re vera velit et quo modo se ad dynamicas quaestiones habeat? STV 1 (1970) $355-359$.

Jankowski A.: Biblijne miejsce Matki Chrystusa w zbawczym planie Bożym. W: Drogi zbawienia, Poznań 1979, Księgarnia św. Wojciecha, S. $253-265$.

Jankowski A.: Znaki czasu w Piśmie świętym, AK 336 (1970) 7-18.

Jankowski A.: Z rozważań nad Nowym Przymierzem, Poznań 1958, Pallottinum, ss. 315.

Kasper W.: Jezus Chrystus, Warszawa 1983, PAX, ss. 316 (zwłaszcza s. $59-161)$.

Kossowska M.: Osobowe właściwości ewangelistów dostrzegane w przekazach treści Dobrej Nowiny i stopień nienaruszalności treści ewangelicznej, „Novum” 4-5 (1977) 8-31.

Kulisz J.: Ewangelia mówiona i Ewangelia spisana, PP 10 (1984) $51-62$.

Langkammer H.: Misterium zbawcze Jezusa Chrystusa i rola Jego Matki w świetle Nowego Testamentu. W: Na rzecz postawy chrześcijańskiej, Warszawa 1978, s. $61-82$. 
Manthey F.: Znaczenie apologetyczne Dziejów Apostolskich, MDG 1 (1947) $407-423$.

Muszyński H.: Etos biblijny. W: Z problematyki etosu biblijnego (pod red. J. Eacha), Warszawa 1980, ATK, s. 9-63. ss. 220.

Romaniuk K.: Nowy Testament bez problemów, Warszawa 1983, ATK,

Rosłon J.: Biblijne przymierze z Bogiem a życie zakonne. W: Z problematyki etosu biblijnego (pod red. J. Łacha), Warszawa 1980, ATK, s. $64-85$.

Szlaga J.: Czy sprzeczności w Nowym Testamencie. W: Studio lectionem facere, s. 126-133.

Szlaga J.: Jezus przeciwnikiem kultu liturgicznego? AK 401 (1975) $312-320$.

Szulc F.: Struktura teologii judeochrześcijańskiej. W świetle badań J. Daniélou, Lublin 1982, RW KUL, ss. 168 (s. 58, 60-61, 63, 65-66, 71, $91,102,126,132,135)$.

White E. G.: Ewangelizacja, Warszawa 1967, Znaki Czasu, ss. 466.

Żołnierczyk B.: Symbolika szaty Chrystusowej (Ek 23, 11). W: Studia z teol. św. Eukasza, s. 172-179.

Żabiński Z.: Trzydzieści srebrników, CT $43: 1973,2$, s. 65-75.

Kraków

KRZYSZTOF PILARCZYK

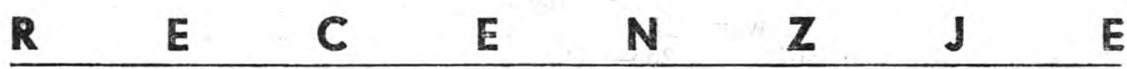

Peshitta. The Old Testament in Syriac according to the Peshitta Version. Part. II, 1a - Job. Leiden 1982, XIX, 55p.

Syryjski tekst Peszitty księgi Hioba został przygotowany przez uczonego szwedzkiego L. G. Rignella, który zmarł przed opublikowaniem swego dzieła dnia 10 X 1981 r. Omawiany tom mógł ujrzeć światło dzienne dzięki pomocy finansowej Szwedzkiej Królewskiej Akademii Literatury.

Oryginalny tekst jest poprzedzony wprowadzeniem (VII-XIX), na które składają się uwagi wstępne, opis rękopisów i lista pozostałych rękopisów. Z uwag wstępnych dowiadujemy się, że tekstem-bazą dla księgi Hioba jest rękopis Ms. B 21 Inferiore znajdujący się w Bibliotece Ambrozjańskiej w Mediolanie. Nadto autor przestudiował 44 biblijne rękopisy, które podzielił na trzy grupy. Rignell wykorzystał lekcjonarze wśród których najważniejsze są $911-3$. 5. 6; 10/2, 11L 1-5. Lista pozostałych manuskryptów obejmuje rękopisy biblijne i lekcjonarze zebrane, ale nie włączone do drugiego aparatu krytycznego, chyba że będzie to zaznaczone strzałką.

Należy powitać z radością wynik żmudnej pracy prof. Rignella. Biblistom zajmującym się księgą Hioba dostarczył wiele cennego materiału porównawczego. 